$1-1-2018$

\title{
Taxing Litigation: Federal Tax Concerns of Personal Injury Plaintiffs and Their Lawyers
}

\author{
Gregg Polsky \\ Francis Shackelford Distinguished Professor in Taxation Law University of Georgia School of Law, \\ gregg.polsky@uga.edu
}

P

\section{Repository Citation}

Gregg Polsky, Taxing Litigation: Federal Tax Concerns of Personal Injury Plaintiffs and Their Lawyers , 22 Fla. Tax Rev. 120 (2018),

Available at: https://digitalcommons.law.uga.edu/fac_artchop/1281

This Article is brought to you for free and open access by the Faculty Scholarship at Digital Commons @ University of Georgia School of Law. It has been accepted for inclusion in Scholarly Works by an authorized administrator of Digital Commons @ University of Georgia School of Law. Please share how you have benefited from this access For more information, please contact tstriepe@uga.edu. 


\title{
FLORIDA TAX REVIEW
}

Volume 22

2018

Number 1

\section{Taxing Litigation: Federal Tax Concerns of Personal INJURY PLAINTIFFS AND THEIR LAWYERS}

\author{
by \\ Gregg D. Polsky*
}

\section{Abstract}

This Article addresses the federal tax concerns of personal injury plaintiffs and the lawyers who represent them, typically on a contingencyfee basis. It explains when plaintiffs' recoveries are taxable for income and employment tax purposes and whether and how those recoveries are required to be reported by defendants to the IRS. It also discusses whether attorney's fees and costs are deductible by plaintiffs.

In addition to these tax planning and compliance issues, the Article also considers when tax evidence might be admissible. Plaintiffs and defendants often try to introduce tax evidence in an effort to increase or decrease, respectively, the amount of damages awarded. These attempts have been met with varying degrees of success, depending on the jurisdiction and context.

The Article then addresses the personal tax issues of trial lawyers themselves. Structured attorney fee arrangements, whereby these lawyers attempt to defer tax on contingent fees, are discussed. The tax deductibility of litigation costs advanced by contingent fee lawyers to their clients is considered. Finally, the Article concludes with a discussion of how provisions of the 2017 Tax Act might affect trial lawyers.

* Francis C. Shackelford Distinguished Professor in Taxation Law, University of Georgia School of Law. Thanks to attendees at the American Association for Justice Annual Convention in Denver, Colorado, for feedback on an earlier draft. This work was supported by a grant from the American Association for Justice Robert L. Habush Endowment. Thanks also to Robert Daily for research assistance. 


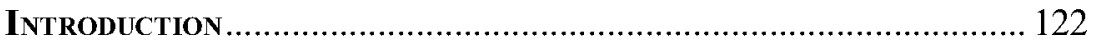

I. Tax Consequences to Personal Injury Plaintiffs ............. 122

A. Foundational Tax Concepts............................................. 122

B. Is the Recovery Included in Plaintiff's Gross Income? ........ 123

1. Broad Exclusionary Rule in Physical Injury Cases ......... 123

2. Three Specific Exceptions .......................................... 124

3. Wrongful Death, Consortium Claims,

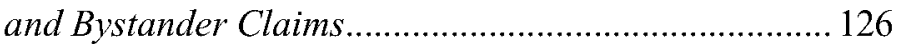

4. Recoveries of Legal Fees and Costs from

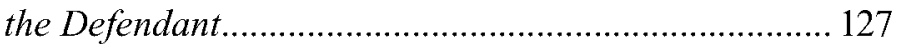

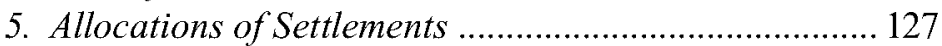

6. Broad Inclusionary Rule in Nonphysical Injury Cases............................................................. 129

7. Distinguishing Between Physical Sickness and Symptoms of Emotional Distress.................................. 130

8. Specific Exclusion for Wrongful Incarceration ............. 131

C. Is the Recovery Subject to Wage Taxes?.......................... 132

D. Deduction for Attorney's Fees and Costs ......................... 133

E. Potential Denial of Deductions for Sexual Harassment/Abuse Claimants? ......................................... 138

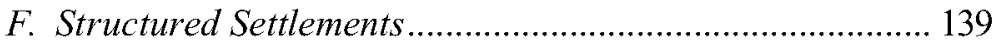

II. Reporting Obligations of Defendants and Insurance

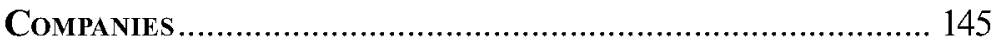

III. Tax Consequences for Defendants ..................................... 147

IV. Admissibility of TAx Evidence......................................... 149

A. Tax Evidence Sought To Be Introduced by Defendants.... 149

B. Tax Evidence Sought To Be Introduced by Plaintiffs ........ 151

1. Adverse Tax Consequences of Recovery ...................... 151

2. Defendant's Tax Benefits from Paying

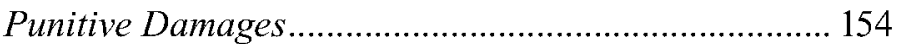

V. Personal Tax Issues of Trial Lawyers ............................... 158

A. Structured Attorney Fees................................................ 158

B. Tax Treatment of Litigation Costs .................................... 165

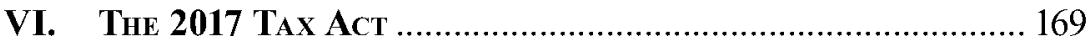

A. The 20\% Pass-Through Deduction ................................. 169

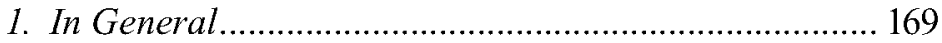

2. Potential Pass-Through Deduction Strategies

for Lawyers.

a. Strategies for Lawyers Below the

Income Thresholds

b. “Cracking” Legal Services Businesses.....................175 
B. Drastically Reduced Corporate Rates.............................. 177

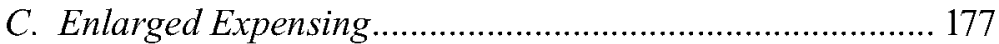

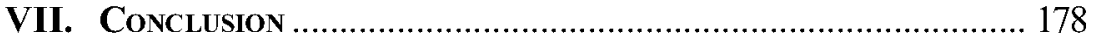

\section{INTRODUCTION}

This Article addresses the federal tax concerns of personal injury plaintiffs and the lawyers who represent them, typically on a contingency-fee basis. Plaintiffs need to know whether their recoveries are taxable and whether their attorney's fees are deductible. Plaintiffs' lawyers need to understand their client's tax concerns and how payments made by defendants or insurance companies will be reported to the Internal Revenue Service (IRS). In addition, litigants may seek to introduce tax evidence to influence the factfinder's calculation of damages. Plaintiffs' lawyers also face their personal tax issues in managing their own legal practices.

While this Article covers all of this ground, it pays particular attention to three important developments stemming from the Tax Cuts and Jobs Act of 2017 (2017 Tax Act). First, certain plaintiffs will no longer be able to deduct their attorney's fees and costs, which can result in extremely high effective tax rates in contingent fee situations. Second, under the so-called "Harvey Weinstein" rule, payments of damages for sexual abuse or harassment accompanied by a nondisclosure agreement are now nondeductible, as are payments of attorney's fees in these cases. Finally, the new tax law created a significant new deduction, known as the pass-through deduction, which may be helpful to some lawyers.

The Article proceeds as follows. Part I addresses the tax concerns of plaintiffs. Part II addresses the tax reporting and withholding requirements imposed on defendants and insurance companies. Part III explains the tax consequences to defendants when they pay settlements or judgments. Part IV discusses the situations where tax evidence may be taken into account by juries or judges in setting the amount of damages. Parts V and VI turn the attention to the tax concerns of plaintiffs' lawyers. Part V analyzes the unique tax issues faced by plaintiffs' lawyers, while Part VI discusses the impact of the 2017 Tax Act on these lawyers.

\section{Tax Consequences to Personal Injury Plaintifys}

\section{A. Foundational Tax Concepts}

Most taxpayers face two types of annual federal taxes: the income tax and the employment tax. The income tax taxes a taxpayer's net income from 
any source, while the employment tax generally taxes a taxpayer's wages. A taxpayer's net income is equal to the excess of the taxpayer's gross income over the taxpayer's deductions. Gross income generally includes all accessions to wealth, ${ }^{1}$ which includes cash receipts that are not offset by any cost (or "tax basis"). Thus, if a taxpayer earns $\$ 100$ of wages or fees, the taxpayer realizes $\$ 100$ of gross income. But if the taxpayer sells stock, which was previously purchased for $\$ 80$ (giving her a tax basis of $\$ 80$ in the stock), for $\$ 100$, she realizes only $\$ 20$ of gross income. Some items of gross income, such as certain damages received on account of personal physical injuries, are specifically excluded from gross income. ${ }^{2}$

A taxpayer has no tax basis in her body or in her physical or emotional well-being, so personal injury victims would realize gross income equal to the entire amount of the recovery, unless the exclusion mentioned above applies. ${ }^{3}$ Thus, for personal injury plaintiffs, a critical threshold issue is whether and to what extent the exclusion applies. If the exclusion does not apply, the award is included gross income. In those cases, a key issue is whether the plaintiff can deduct her attorney's fees. In addition, where the exclusion does not apply, an important issue is whether any portion of the recovery is also subject to wage taxes.

\section{B. Is the Recovery Included in Plaintiff's Gross Income?}

\section{Broad Exclusionary Rule in Physical Injury Cases}

Section 104(a)(2) provides a significant exclusion from gross income for damages "on account of personal physical injuries or physical

1. See generally I.R.C. $§ 61$; Comm'r v. Glenshaw Glass Co., 348 U.S. 426 (1955).

2. See I.R.C. \$ 104(a)(2).

3. However, if the recovery includes a component for damage to property, such as to the taxpayer's car, the portion of the recovery attributable to the property would be offset by the taxpayer's basis in the car and would reduce such basis. For example, if a car accident plaintiff recovers $\$ 10,000$ for damage to her personal car, which she had bought for $\$ 25,000$, the plaintiff would not realize any gross income with respect to that $\$ 10,000$. Instead, the $\$ 10,000$ would reduce her basis in the car down from $\$ 25,000$ to $\$ 15,000$. If she spent the $\$ 10,000$ to repair the car, her basis in the car would go back up to $\$ 25,000$. See Big Four Indus., Inc. v. Comm'r, 40 T.C. 1055, 1060 (1963), acq., 1964-2 C.B. 3, 4; Reg. $\$ 1.263$ (a)-3(k)(1)(iii); F.S.A. 2002-28-005 (Mar. 29, 2002); P.L.R. 93-08-013 (Nov. 24, 1992). 
sickness." Subject to only a few exceptions detailed below, if a claim originates in a physical injury or sickness, the resulting damages are excluded from gross income and therefore tax-free. Thus, in claims involving car accidents, medical malpractice, slips-and-falls, products liability, and batteries, recoveries that represent pain and suffering, mental anguish, disfigurement, physical disability or impairment, inconvenience, loss of capacity for the enjoyment of life, lost wages (past or future), and medical expenses (past or future) are generally excluded from gross income. ${ }^{5}$

\section{Three Specific Exceptions}

While most categories of damages received in a physical injury case are excluded, there are three exceptions. First, punitive damages are included in gross income and therefore taxable. ${ }^{6}$ Likewise, any portion of the award that represents pre- or post-judgment interest is taxable. ${ }^{7}$ Finally, any recovery of prior out-of-pocket medical expenses that were previously claimed as a deduction is taxable. ${ }^{8}$

4. Emphasis added.

5. See Rev. Rul. 85-97, 1985-2 C.B. 50 (in settlement arising out of bus accident resulting in bodily injury, the entire settlement was excluded from gross income, including the portion allocable to lost wages).

6. I.R.C. $\$ 104(a)(2)$ (providing for exclusion in personal physical injury and physical sickness cases for damages "other than punitive damages"). There is a narrow exception to this rule in section 104(c). That provision allows for punitive damages arising out of a physical injury to be excluded in a wrongful death case where the applicable state wrongful death law (as in effect on September 13, 1995) provides, or has been construed by a court to provide, that only punitive damages may be awarded in such an action. See also Benavides v. United States, 497 F.3d 526, 530 (5th Cir. 2007) (holding that section 104(c) does not exclude punitive damages when the general wrongful death laws of the state do not limit recovery to punitive damages, even if some other law, such as workers' compensation law, might have such a limit).

7. See Chamberlain v. United States, 401 F.3d 335, 347 (5th Cir. 2005) (holding that prejudgment interest is taxable even where other components of the award were tax-free under section 104(a)(2)); Delaney v. Comm'r, 99 F.3d 20, 27 (1st Cir. 1996) (same); Brabson v. United States, 73 F.3d 1040, 1047 (10th Cir. 1996) (same); Kovacs v. Comm'r, 100 T.C. 124, 132-33 (1993) (same).

8. See I.R.C. $\$ 104$ (a) (carving out from the exclusion "amounts attributable to (and not in excess of) deductions allowed under section 213 
The inclusionary rule for previously deducted medical expenses is typically of little significance. First, due to private insurance, Medicare, Medicaid, or the fact that they lack the financial ability to pay, plaintiffs often do not pay large amounts of medical expenses out of pocket. Second, medical expenses are only deductible to the extent that the aggregate amount of out-of-pocket medical expenses paid during the year exceeds 7.5 or $10 \%{ }^{9}$ of the taxpayer's adjusted gross income for that year. ${ }^{10}$ Third, only taxpayers who itemize their deductions (in lieu of claiming the standard deduction) can deduct medical expenses. Historically, about one-third of taxpayers itemized their deductions, but the 2017 Tax Act will dramatically reduce this percentage because it nearly doubled the standard deduction while limiting or eliminating a host of itemized deductions. ${ }^{11}$ The bottom line is that few plaintiffs will have received a tax benefit from previously deducted medical expenses, which means that any recovery of those expenses will not be taxed. ${ }^{12}$

On the other hand, the inclusions in gross income of punitive damages and interest can be significant in certain cases. In a case involving egregious conduct by a defendant in a physical injury case, the IRS could assert that a significant portion of the plaintiff's recovery

(relating to medical, etc., expenses) for any prior taxable year"). The inclusion in gross income of the recovery of previously deducted medical expenses effectively reverses out the prior deduction for expenses that are not (after the recovery) financially borne by the plaintiff.

9. Due to statutory amendments, the "floor" has bounced between $7.5 \%$ and $10 \%$. In 2018 , the floor is $7.5 \%$, but it is scheduled to rise to $10 \%$ beginning in 2019. I.R.C. $\S 213(\mathrm{f})(2)$.

10. I.R.C. $\S 213$. Adjusted gross income generally equals the taxpayer's gross income less business deductions. I.R.C. $§ 62$.

11. For married taxpayers, the standard deduction was $\$ 12,700$ in 2017, while it is $\$ 24,000$ in 2018. I.R.C. $\$ 63$ (c)(7); Rev. Proc. 2016-55, 2016-2 C.B. 707. The 2017 Tax Act also capped the state and local tax deduction at $\$ 10,000$, whereas before it was unlimited. I.R.C. $\$ 164(b)(6)$.

12. Recoveries representing future medical expenses are tax-free. See Rev. Rul. 75-232, 1975-1 C.B. 94 (the "dollars designated for future medical expenses relating to the injuries suffered [are] excludable from gross income under the provisions of section 104(a)[(2)] of the Code"). However, the plaintiff will be denied a deduction in the future for medical expenses that are paid out of the recovery. Thus, if the plaintiff receives $\$ 100,000$ for future medical costs, the first $\$ 100,000$ of medical expenses paid will not be eligible for a deduction under section 213. See id. 
represents taxable punitive damages. And in a physical injury case involving a lengthy appeal, a large portion of the plaintiff's recovery may constitute taxable post-judgment interest.

\section{Wrongful Death, Consortium Claims, and Bystander Claims}

In wrongful death and loss of consortium claims, the plaintiff (the estate or spouse) is not the direct victim of the physical injury or sickness. Nevertheless, the legislative history makes clear that these recoveries were intended to be covered by the section 104(a)(2) exclusion:

If an action has its origin in a physical injury or physical sickness, then all damages (other than punitive damages) that flow therefrom are treated as payments received on account of physical injury or physical sickness whether or not the recipient of the damages is the injured party. For example, damages (other than punitive damages) received by an individual on account of a claim for loss of consortium due to the physical injury or physical sickness of such individual's spouse are excludable from gross income. ${ }^{13}$

This approach has been followed by the IRS in private letter rulings involving wrongful death and consortium claims. ${ }^{14}$

It is not clear whether damages would be excluded in bystander claims where the link between the damages and the physical injury is more tenuous. For example, in California a plaintiff may recover for the emotional disturbance of witnessing an accident that causes physical harm to a close relative. ${ }^{15}$ Arguably, such a claim is "an action [that] has its origin in a physical injury" and the damages "flow therefrom," as required by the legislative history quoted above. However, there are no tax cases or rulings that address this specific situation.

13. H.R. REP. No. 104-737, at 301 (1996) (Conf. Rep.), as reprinted in 1996 U.S.C.C.A.N. 1677, 1793.

14. See P.L.R. 2001-21-031 (Feb. 16, 2001) (loss of consortium damages in asbestos case excluded); P.L.R. 2000-29-020 (Apr. 18, 2000) (wrongful death damages received by estate stemming from automobile accident excluded).

15. See Dillon v. Legg, 441 P.2d 912, 925 (Cal. 1968). 


\section{Recoveries of Legal Fees and Costs from the Defendant}

If a claim is fully covered by section 104(a)(2) so that all damages are excluded from gross income, any recovery of legal fees or court costs from the defendant is likewise excluded ${ }^{16}$ If a claim is only partially covered by section 104(a)(2) because, for example, a portion of the recovery represents interest or punitive damages, then the recovered fees must be allocated between the taxable and tax-free portions of the award, and courts and the IRS typically use a pro rata allocation. ${ }^{17}$ For example, if a physically injured plaintiff recovers $\$ 1,000,000$ in compensatory damages, ${ }^{18} \$ 300,000$ in punitive damages, $\$ 200,000$ in interest, and $\$ 300,000$ in statutory legal fees, the legal fees must be allocated between the taxable portion of the recovery (the punitive damages and interest) and the tax-free portion (the compensatory damages) on a pro rata basis. Because the taxable portion totals $\$ 500,000$ and the tax-free portion totals $\$ 1,000,000$, one-third $(\$ 100,000)$ of the legal fees are included in gross income and the remaining two-thirds $(\$ 200,000)$ are tax-free. The plaintiff therefore must include in gross income $\$ 600,000$ of the total $\$ 1.8$ million recovery.

\section{Allocations of Settlements}

Where a portion of an otherwise tax-free recovery is taxable (because the portion represents punitive damages, interest, or a recovery of previously deducted medical expenses), an allocation is necessary to determine the taxable component. If a judgment is paid in full, the allocation will typically be easy because the verdict will differentiate the damage components. When, as is far more common, the case settles before trial, allocations are much more difficult.

Well-advised parties will typically enter into a specific allocation in the settlement agreement, and courts give some degree of

16. See e.g., Fite v. Comm'r, T.C. Memo 1993-594, 66 T.C.M. (CCH) 1588 (1993).

17. See Johnson-Waters v. Comm'r, T.C. Memo 1993-333, 66 T.C.M. (CCH) 252 (1993); P.L.R. 2004-03-046 (Jan. 16, 2004).

18. Assume that none of the compensatory damages represents a recovery of previously deducted medical expenses. Otherwise, that portion of the compensatory damages would be taxable and would change the calculations. See I.R.C. $\S 104(a)$. 
deference to the parties' agreed allocation. ${ }^{19}$ However, the IRS and some courts have realized that, no matter how adversarial the parties are before reaching a financial compromise, they are not adversarial in making allocations because the defendant's tax consequences will be the same regardless. ${ }^{20}$ Furthermore, defendants often strongly prefer to disclaim that they are paying any punitive damages due to public relations or insurance concerns; therefore, the parties are strongly aligned in desiring to avoid making explicit allocations to punitive damages. ${ }^{21}$ In fact, it is rare if not unprecedented to see a settlement agreement that specifically allocates amounts to punitive damages. ${ }^{22}$

19. See, e.g., McKay v. Comm'r, 102 T.C. 465, 482 (1994), vacated on other grounds, 84 F.3d 433, 1996 U.S. App. LEXIS 45181 (5th Cir. 1996) (concluding that an express allocation in a settlement agreement is the "most important factor" in allocating settlements among various components); Byrne v. Comm'r, 90 T.C. 1000, 1007 (1988), rev'd on other grounds, 883 F.2d 211 (3d Cir. 1989) (same).

20. See Bagley v. Comm'r, 121 F.3d 393, 396 (8th Cir. 1997) (noting that "when the time comes to settle a case, no matter how adversarial the proceedings have been to that point, the parties will almost always be in agreement that no part of a settlement agreement should be explicitly allocated to punitive damages" and concluding that non-adversarial allocations should be scrutinized).

21. See Robert W. Wood, Tax Aspects of Settlements and Judgments, 522-4th TAx MGMT. PorT. (BNA) § III.E (noting that, even leaving aside tax consequences, "it would be highly atypical for a settlement agreement to acknowledge that any portion of the settlement was paid on account of punitive damage" and that "[v] irtually no defendant would agree to such a characterization"); Bagley, 121 F.3d at 396 ("It will almost never be to a defendant's advantage to allocate part of a lump-sum settlement to punitive damages, and it will often be disadvantageous. Often, insurance policies will not cover such awards, and punitive-damage awards result in worse publicity than compensatory awards. Most plaintiffs will not want specific allocations to punitive damages in their settlement agreements, because punitive damages are taxable.").

22. See Bagley, 121 F.3d at 396 n.7 (noting that the defendant's attorney, "an experienced Iowa litigator, told the Tax Court that he could recall no settlement with which he had been involved that specifically allocated a certain amount to punitive damages in the settlement agreement"); Tom Baker, Transforming Punishment into Compensation: In the Shadow of Punitive Damages, 1998 Wis. L. REv. 211, 218 (explaining that none of the thirty prominent personal injury lawyers interviewed "reported ever settling a case for an 
Despite this skepticism, allocations in settlement agreements are still helpful, provided that they are reasonable. ${ }^{23}$ In addition to considering an express allocation in a settlement agreement, the IRS and courts will evaluate the relevant facts and circumstances surrounding the underlying claim and the course of litigation to determine the true economic substance of the settlement. Plaintiffs' lawyers should be aware that their court filings and other work product could eventually become relevant evidence in a tax dispute between their client and the IRS. Some commentators recommend that plaintiffs' lawyers avoid highlighting the punitive nature of the plaintiff's claims in court filings and other documents. ${ }^{24}$

\section{Broad Inclusionary Rule in Nonphysical Injury Cases}

The broad exclusionary rule in section 104(a)(2) applies only to personal injury claims that involve a physical injury or sickness. ${ }^{25}$ The statute makes clear that emotional distress is not treated as a physical injury or sickness. ${ }^{26}$ The legislative history explained that Congress intended for emotional distress to include "physical symptoms (e.g., insomnia, headaches, and stomach disorders) which may result from such emotional distress." 27 The IRS and courts have adhered to this approach of not treating physical symptoms of emotional distress as a physical injury

amount that included a portion identified as "punitive damages"'); Wood, supra note 21 (stating that such an allocation would be "highly atypical").

23. See Brent B. Nicholson \& Douglas K. Chapman, Enforceability of Settlement Allocations Under Section 104(a)(2) of the Internal Revenue Code, 47 BAYLOR L. REV. 97, 113 (1995) (arguing that express allocations in settlement agreements "shift the debate to the issue of enforceability, which . . . [should be] an easier argument for [the taxpayer] to win").

24. See, e.g., Kevin A. Palmer, Recent Developments in the Taxation of Punitive Damages Awards, 73 TAXEs 596, 600 (1995) (arguing that plaintiffs should avoid making punitive damage claims in their initial complaint to strengthen tax position that entire settlement is allocated to compensatory damages).

25. Emphasis added.

26. I.R.C. $\$ 104$ (a) (flush language) (stating that, for purposes of the section 104(a)(2) exclusion, "emotional distress shall not be treated as a physical injury or physical sickness").

27. See H.R. ReP. No. 104-737, supra note 13, at 369 n.56. 
or sickness which triggers the application of the broad section 104(a)(2) exclusion..$^{28}$

Thus, while emotional distress damages that stem from physical injuries or sickness are not taxed, ${ }^{29}$ in "pure" emotional distress cases and other nonphysical injury cases all damages are taxed with one minor exception. The one exception is for damages that represent a recovery of out-of-pocket medical expenses attributable to the emotional distress, such as psychiatrist's bills, that were not previously deducted by the plaintiff. ${ }^{30}$

The following are examples of common nonphysical injury claims to which the broad inclusionary rule generally applies: employment discrimination, sexual harassment, intentional or negligent infliction of emotional distress, defamation, malicious prosecution, invasion of privacy, false imprisonment, fraud, trespass, and nonphysical civil rights claims. ${ }^{31}$ In these cases, the plaintiff often must include the full recovery in gross income.

\section{Distinguishing Between Physical Sickness and Symptoms of Emotional Distress}

In light of the significant tax distinction made between physical sickness and emotional distress claims, it is not surprising that plaintiffs

28. See, e.g., Lindsey v. Comm'r, 422 F.3d 684, 688 (8th Cir. 2005) (in applying section 104(a)(2) "hypertension and stress-related symptoms, including periodic impotency, insomnia, fatigue, occasional ingestion and urinary incontinence" were mere symptoms of emotional distress rather than a physical sickness); Banaitis v. Comm'r, 340 F.3d 1074 (9th Cir. 2003), rev'd on other grounds sub nom. Comm'r v. Banks, 543 U.S. 426 (2005); Gutierrez v. Comm'r, T.C. Memo 2011-263, 102 T.C.M. (CCH) 480 (2011).

29. Reg. § 1.104-1(c)(1) (explaining that "damages for emotional distress attributable to a physical injury or physical sickness are excluded from income under section 104(a)(2)"). Recall that all damages that flow from a physical injury or sickness are excluded, except for punitive damages, interest, and previously deducted medical expenses.

30. I.R.C. $\$ 104$ (a) (flush language) (providing that, solely for outof-pocket medical expenses, emotional distress shall be treated as a physical injury).

31. See e.g., Stadnyk v. Comm'r, T.C. Memo 2008-289, 96 T.C.M. (CCH) 475, 478 (2008) ("physical restraint and physical detention" in a false imprisonment case are not "physical injuries" under section 104(a)(2)). 
often try to fit into the former category. While the IRS and courts consistently find, based on the legislative history, that "symptoms" or "manifestations" of emotional distress (such as ulcers and migraines) do not suffice, ${ }^{32}$ other more extreme medical conditions occasionally do. For example, in Domeny v. Commissioner, ${ }^{33}$ a plaintiff's pre-existing multiple sclerosis condition was allegedly exacerbated by emotional distress stemming from workplace problems, and the Tax Court held that this exacerbation constituted a physical sickness under section 104(a)(2). Likewise, in Parkinson v. Commissioner, the plaintiff suffered a heart attack allegedly from emotional distress caused by his employer's conduct. ${ }^{34}$ The Tax Court found that it "would seem self-evident that a heart attack and its physical aftereffects constitute a physical injury or sickness rather than mere subjective sensations or symptoms of emotional distress." 35 These cases suggest that where the plaintiff's physical reactions to emotional distress are quite severe, they should be welldocumented so as to buttress the argument that damages are excluded under section 104(a)(2).

\section{Specific Exclusion for Wrongful Incarceration}

While damages from private false imprisonment cases are generally taxable due to the absence of a physical injury or sickness, ${ }^{36}$ payments made for wrongful incarceration by the government are now specifically excluded from gross income under section 139F. Section 139F became effective in December 2015.

32. See, e.g., Blackwood v. Comm'r, T.C. Memo 2012-190, 104 T.C.M. (CCH) 27, 30 (2012) (entire settlement taxable where taxpayer suffered a relapse of depression, which resulted in insomnia, migraines, and other physical conditions, because these "physical symptoms of depression were [not] severe enough to rise to the level of a physical injury or sickness").

33. Domeny v. Comm'r, T.C. Memo 2010-9, 99 T.C.M. (CCH) 1047 (2010).

34. Parkinson v. Comm'r, T.C. Memo 2010-142, 99 T.C.M. (CCH) $1583(2010)$.

35. Id. at 1586.

36. See Stadnyk, 96 T.C.M. (CCH) at 478 ("[P]hysical restraint and physical detention are not 'physical injuries' for purposes of section 104(a)(2)."). 


\section{Is the Recovery Subject to Wage Taxes?}

Employment taxes are imposed on wages received by a taxpayer. In some cases, recoveries of damages are considered wages. However, if the defendant is not a former, current, or would-be (in refusal to hire cases) employer of the plaintiff, none of the recovery will be characterized as wages. In addition, to the extent a recovery is excluded from gross income under section 104(a)(2) (because it arises out of a personal physical injury or sickness), it does not constitute wages.

Where the defendant is a former, current, or would-be employer and the recovery is taxable, the portions of the recovery that constitute back pay or severance pay are clearly considered wages, ${ }^{37}$ and the IRS's position is that the portion representing front pay is also treated as wages, ${ }^{38}$ though one court has disagreed. ${ }^{39}$ On the other hand, amounts attributable to emotional distress, medical expenses, interest,

37. See United States v. Quality Stores, Inc., 572 U.S. 141, 156 (2014) (severance pay is considered wages); Soc. Sec. Bd. v. Nierotko, 327 U.S. 358, 370 (1946) (back pay is considered wages). In refusal to hire cases (where no formal employment relationship is ever created), the IRS's position is that the payments made are characterized as back pay and therefore constitute wages (Rev. Rul. 78-176, 1978-1 C.B. 303), but the Eighth Circuit has disagreed (Newhouse v. McCormick \& Co., 157 F.3d 582 (8th Cir. 1998)). The IRS likewise takes the position that lost wages and benefits paid under the Family Medical \& Leave Act (FMLA) constitute wages, but the Eastern District of Pennsylvania has disagreed based on the particular language in the FMLA. Carr v. Fresenius Med. Care, No. 05-2228, 2006 U.S. Dist. LEXIS 29627 (E.D. Pa. May 16, 2006); Churchill v. Star Enters., 3 F. Supp.2d 622 (E.D. Pa. 1998). But see Cheetham v. CSX Transp., No. 3:06-cv-704-J-PAM-TEM, 2012 U.S. Dist. LEXIS 49659 (M.D. Fla. Feb. 13, 2012) (declining to follow Carr and Churchill and holding that FMLA lost wages and benefits are wages). Payments made to cancel or buy out an employment contract are also considered wages by the IRS. See Rev. Rul. 2004-110, 2004-2 C.B. 960.

38. Field Att'y Adv. 2013-3501F (July 11, 2013) (noting that the IRS's position is that front pay constitutes wages); see also Gerbec v. United States, 164 F.3d 1015, 1026 (6th Cir. 1999).

39. See Dotson v. United States, 87 F.3d 682, 689-90 (5th Cir. 1996) (holding, since front pay compensates for a "loss in earning capacity," it is not considered wages, even though back pay is). But see Gerbec, 164 F.3d at 1026 (holding that front pay, like back pay, is wages); Mayberry v. United States, 151 F.3d 855, 860 (8th Cir. 1998) (same); Hemelt v. United States, 122 F.3d 204, 209 (4th Cir. 1997) (same). 
reimbursement of attorney's fees and court costs, statutory penalties, ${ }^{40}$ and punitive damages are not considered wages. ${ }^{41}$ Therefore, allocations between wage and non-wage portions will be necessary in employmentrelated settlements that involve payments in both categories. Because wage taxes are paid by both employers and employees, both parties have a tax incentive to minimize allocations to the wage portions. While specific allocations in settlement agreements are given some weight by courts, the IRS is well aware that allocations away from wages are self-serving for both parties. ${ }^{42}$ Therefore, allocations in settlement agreements should reasonably reflect the economic substance of the settlement. ${ }^{43}$

\section{Deduction for Attorney's Fees and Costs}

If a plaintiff's recovery is entirely excluded from gross income, he or she may not claim any deduction for legal fees or costs paid because taxpayers cannot deduct expenses attributable to tax-exempt income. ${ }^{44}$ However, if some or all of the recovery is taxable, then the plaintiff may be able to deduct some or all of those fees and costs. In the 2004 case of Commissioner v. Banks, ${ }^{45}$ the U.S. Supreme Court confirmed that, in a contingent fee arrangement, the plaintiff must include the entire amount of the recovery (including the attorney-fee portion) in gross income. This is true whether the defendant writes two checks - one to the attorney

40. But see I.R.S. Info. Ltr. 2005-0094 (Mar. 17, 2005) (explaining that penalties under California Labor Code section 226.7 for failure to provide the employee with a meal or rest period are considered wages).

41. See, e.g., T.A.M. 2002-44-004 (June 19, 2002) (determining that emotional distress payments and reimbursement of attorney fees and costs paid by employer are not wages).

42. See supra notes 19-22 and accompanying text.

43. In addition, the IRS has determined that in some situations a failure to explicitly allocate amounts in a settlement agreement will preclude a taxpayer from making an allocation to a non-wage element. Specifically, the IRS determined that a failure to specifically allocate a portion of an award to the recovery of statutory attorney fees in an employment-related case resulted in the entire settlement being characterized as wages. See Field Att'y Adv. 2013-3501F (July 11, 2013).

44. See I.R.C. $\$ 265(a)$.

45. 543 U.S. 426 (2005). Note that the IRS has recognized one exception to the Banks rule. In so-called "opt-out" class action litigation, the IRS has ruled that attorney fees paid by non-lead plaintiffs are not included in gross income. See, e.g., P.L.R. 2009-06-010 (Oct. 24, 2008). 
for the attorney-fee portion of the settlement and the other for the remainder to the plaintiff - or only one check to the attorney, who thereafter remits the amount remaining after fees to the plaintiff. In other words, regardless of the formalities of payment, the plaintiff is treated for tax purposes as if she receives the gross settlement amount and then pays her own attorney for fees and costs. ${ }^{46}$

In other words, Banks re-characterized the parties' formal arrangement. Formally, the defendant paid the plaintiff's attorney directly as depicted in Figure 1:

\section{Figure 1:}

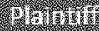

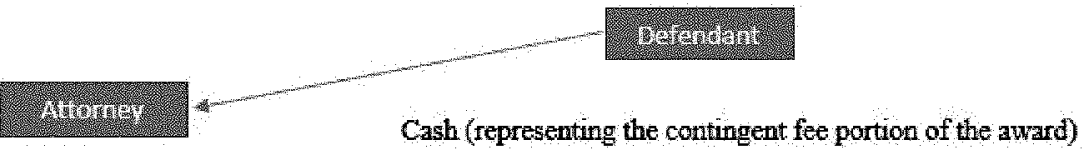

However, under Banks, the transaction is re-characterized, for income tax purposes, as follows:

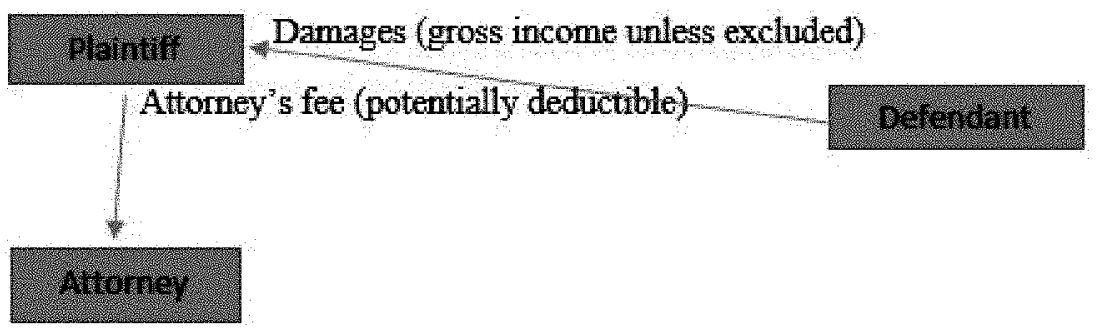

Thus, under Banks, the plaintiff is no longer a mere bystander; instead, the contingent fee portion of the recovery is deemed to flow through the plaintiff on its way to the plaintiff's attorney. This has significant implications in cases where the plaintiff's attorney's fee is not fully deductible.

For example, assume that in a nonphysical injury case, a plaintiff settles a case for $\$ 1,000,000$. Pursuant to the settlement, the

46. The same rule even applies if attorney's fees are awarded under a federal or state fee-shifting statute. Regardless of the formalities of payment (i.e., two checks or one), the plaintiff is deemed for tax purposes to receive the entire recovery (including the statutory attorney's fees) and then to pay over an appropriate amount of that recovery to the attorney. See Program Manager Tech. Adv. 2009-035 (Oct. 22, 2008). 
defendant delivers a check for $\$ 1,000,000$ to the plaintiff's attorney, who remits a $\$ 600,000$ check to the plaintiff and keeps the remaining $\$ 400,000$ as the attorney's fee. Under Banks, the plaintiff must include the gross $\$ 1,000,000$ settlement in gross income, rather than just the $\$ 600,000$ net payment that she receives. She is also treated as making a $\$ 400,000$ payment to her attorney. If the payment is fully deductible, the plaintiff's net taxable income from settlement would equal $\$ 600,000$ $(\$ 1,000,000$ of gross income less a $\$ 400,000$ deduction), which puts her in the same place had she just included the net settlement amount $(\$ 600,000)$ in gross income in the first place. But, critically, in some cases the plaintiff will not be able to deduct the attorney fee payment, which results in the plaintiff getting taxed on the gross $\$ 1,000,000$ settlement even though she only walks away with $\$ 600,000$ of cash. ${ }^{47}$ In those cases, the plaintiff has $\$ 400,000$ of phantom income.

Thus, in taxable recovery situations, a critical issue is whether the plaintiff can deduct attorney's fees and costs. Fortunately, in most taxable recovery situations, the plaintiff can. But in some situations the plaintiff cannot, and the resulting tax consequences can be devastating. In fact, in extreme cases, the tax burden to the plaintiff can be greater than the amount of cash she walks away with, turning a pre-tax winner into an after-tax loser.

A deduction for attorney's fees and costs is allowed in business- and employment-related cases, as well as in federal, state, or local civil rights claims and actions based on violations of certain federal statutes. ${ }^{48}$ Other taxable recoveries however result in no deduction. Thus,

47. Banks stands for the proposition that the attorney fee portion of a recovery is included in the plaintiff's gross income. The IRS recognizes one exception to this rule. In opt-out class action litigation, the IRS allows the class action members to treat their net recovery (i.e., net of attorney fees and costs) as the amount of the gross income inclusion (in cases where the recovery is taxable). However, in opt-in class action litigation, the traditional Banks no-netting rule applies.

48. See I.R.C. § 62(a)(1) \& (20), (e). These provisions cause the attorney fee deduction to constitute an "above-the-line" deduction. This status prevents the deductions from being classified as miscellaneous itemized deductions, which as discussed below are disallowed. See I.R.C. § 63(d) (defining itemized deductions as deductions other than above-the-line deductions), $\$ 67(\mathrm{~b})$ (characterizing certain itemized deductions as miscellaneous itemized deductions). Some have raised the possibility that section $67(\mathrm{~g})$ 's denial of miscellaneous itemized deductions might somehow affect section 62(a)(20)'s grant of 
plaintiffs who recover for negligent or emotional infliction of emotional distress, defamation, ${ }^{49}$ false imprisonment, loss of consortium claims not based on the family member's physical injury or sickness, ${ }^{50}$ fraud ${ }^{51}$ bad-faith insurance practices, or trespass on personal-use property will typically receive no deduction for attorney's fees and costs.

In addition, physical injury plaintiffs who receive taxable components (such as punitive damages and interest) cannot deduct the attorney's fees and costs that are attributable to those portions. For example, assume that a physically injured plaintiff recovers $\$ 1,000,000$ of compensatory damages and $\$ 2,000,000$ of punitive damages (or interest) and pays a $\$ 1,000,000$ contingent fee. When a plaintiff's recovery is partially taxable and partially tax-free, the attorney's fees and costs must be equitably apportioned between the two components, and courts and the IRS generally pro rate the fees. ${ }^{52}$ Because one-third of the recovery is tax-free, $\$ 333,333$ of the fees are attributable to that portion and therefore nondeductible under the general tax rule that expenses that generate tax-free income are nondeductible. The remaining two-thirds $(\$ 666,667)$ are attributable to the taxable punitive damages and should in theory be deductible. However, under current tax law they are not. The end result is that the plaintiff is taxed on the full $\$ 2,000,000$ of

above-the-line status to deductions for employment and civil rights plaintiffs. See, e.g., Robert W. Wood, Legal Settlements with Tax Indemnities Are on the Rise, 160 TAx Notes 687, 688 (July 30, 2018). This concern however is misplaced because a deduction must first be characterized as an itemized deduction and because itemized deductions and above-the-line deductions are mutually exclusive. For further discussion, see Gregg D. Polsky, Letter to the Editor, Miscellaneous Itemized Deductions and Litigation Expenses, 160 TAX NotEs 1281 (Aug. 27, 2018).

49. If the defamation has its origins in the taxpayer's business (as opposed to the taxpayer's personal life), then the attorney's fees and costs are deductible as business expenses. See I.R.C. $\$ 162(\mathrm{a})$.

50. See, e.g., In re Elkins, 562 B.R. 686, 691-92 (Bankr. N.D. Ohio 2016) (holding that the section $139 \mathrm{~F}$ exclusion does not apply to loss of consortium claims based on wrongful incarceration of a family member).

51. Fraud recoveries are tax-free to the extent they reimburse the plaintiff for amounts lost in the fraud. But to the extent the fraud recovery is greater than the amounts lost (e.g., due to interest or punitive damages), the award is taxable, but the related attorney fees would be nondeductible.

52. See supra note 17 and accompanying text. 
punitive damages (or interest) without any offset for any portion of the $\$ 1,000,000$ of attorney's fees paid.

In cases where the deduction is denied (other than for the reason that the award is tax-free), plaintiffs historically did receive a type of a type of deduction known as a "miscellaneous itemized deduction." But, by virtue of the 2017 Tax Act, beginning in 2018 and continuing through 2025, all miscellaneous itemized deductions are now disallowed in their entirety. ${ }^{53}$ Beginning in 2026, miscellaneous itemized deductions will be allowed again, though they will be subject to certain limitations that applied to them before 2018. ${ }^{54}$

Even before the 2017 Tax Act, the netting rule in Banks, combined with the pre-2018 limitations on miscellaneous itemized deductions, stimulated tax experts to try to think of creative ways to re-characterize or restructure the payment of contingent fees. ${ }^{55}$ Because the 2017 Tax

53. See I.R.C. $\$ 67(\mathrm{~g})$ (suspending miscellaneous itemized deductions through 2025).

54. Before 2018 and after 2025, miscellaneous itemized deductions are only allowed to the extent that they in the aggregate exceed $2 \%$ of the taxpayer's adjusted gross income. I.R.C. § 62(a). In addition, under the alternative minimum tax, miscellaneous itemized deductions are completely disallowed. I.R.C. $\$ 56(\mathrm{~b})(1)(\mathrm{A})(\mathrm{i})$.

55. Some commentators argue that the plaintiff's attorney fee should be capitalized and treated as an offset against the plaintiff's gross settlement. See Joseph M. Dodge, The Netting of Costs Against Income Receipts (Including Damage Recoveries) Produced by Such Costs, Without Barring Congress from Disallowing Such Costs, 27 VA. TAX. REv. 297, 334-47 (2007); Charles Davenport, Why Tort Legal Fees Are Not Deductible, 97 TAx Notes 703, 703-05 (Nov. 4, 2002). But see Brant J. Hellwig \& Gregg D. Polsky, Litigation Expenses and the Alternative Minimum Tax, 6 FLA. TAx Rev. 899, 915, 921 (2004). Others have argued that the plaintiff and the attorney could be considered to have entered into a partnership for tax purposes. See, e.g., John Bogdanski, Contingent Fees: The Partnership Theory Is Sound, 105 TAx Notes 426 (Oct. 18, 2004). The Tax Court has rejected this argument on factual grounds in a typical contingent fee setting. See Bagley v. Comm'r, 105 T.C. 105 T.C. 396, 419 (1995), aff'd, 121 F.3d 393, 396 (8th Cir. 1997) ("Based on the record, we find that there is nothing to indicate that the parties intended the contingency fee arrangement to be a joint venture or partnership. [The attorney] testified that he regarded the arrangement between himself and [the plaintiff] as nothing more than an arrangement for the payment for his services."). Even if a partnership were created, it is doubtful that it would help plaintiffs avoid the miscellaneous itemized deduction problem. See Douglas Kahn, 
Act made matters far worse for plaintiffs who incur miscellaneous itemized deductions, these ideas will surely generate even more interest. To date, however, their efficacy has not been tested before the IRS or in court. ${ }^{56}$

Since miscellaneous itemized deductions are scheduled to spring back to life in 2026, deferring attorney fee payments until then might be an option worth considering in certain cases. Attorney fee structures, described below in Part V.A., could be used in this regard. This strategy is discussed further in that Part.

\section{E. Potential Denial of Deductions for Sexual Harassment/Abuse Claimants?}

The 2017 Tax Act added new Code section 162(q), informally known as the "Harvey Weinstein rule," which provides:

(q) Payments related to sexual harassment and sexual abuse.-No deduction shall be allowed under this chapter for-

(1) any settlement or payment related to sexual harassment or sexual abuse if such settlement or payment is subject to a nondisclosure agreement, or

(2) attorney's fees related to such a settlement or payment.

Section 162(q)(2)'s denial of attorney's fees seems focused on the attorney's fees of defendants not plaintiffs for three reasons. First, section 162(q)(1) disallows deductions for the underlying "settlement or payment," which obviously applies only to defendants. Second, the word

Partnership Theory Won't Help Taxpayers in Contingent Attorney Fee Cases, 105 Tax Notes 885 (Nov. 8, 2004); Gregg D. Polsky, Contingent Fees: Why the Partnership Theory Doesn't Work, 104 TAX Notes 1089 (Sept. 6, 2004). For citations to more back-and-forth over the partnership theory, see Hellwig \& Polsky, supra, at 913-15. Both the capitalization and partnership theories were raised by the taxpayer late in the Banks litigation, but the Supreme Court expressly declined to consider them due to the fact that the arguments had not been raised in the lower courts. Comm'r v. Banks, 543 U.S. 426, 437-38 (2005).

56. One commentator has recently suggested that affected plaintiffs drop their claims into a trust. Lawrence J. Eisenberg, The Contingency Fee Tax Trap and a Solution, DaILY TAX ReP. (BNA), Aug. 22, 2018. 
"payment" in both (q)(1) and (q)(2) can never apply to a plaintiff, who only receives amounts "related to sexual harassment or sexual abuse" and will not pay any such amounts. In other words, the use of the word "payment" suggests a focus on payers of damages not recipients of them. Third, the legislative context indicates that Congress had intended to punish payers of defendants covering up harassment, not victims of harassment. Nevertheless, the "attorney's fees related to such a settlement" language is arguably broad enough to capture the plaintiff-side attorney's fees attributable to a settlement of harassment cases. Ordinarily such fees would be deductible in nonphysical injury cases in employment and civil rights cases. ${ }^{57}$ Senator Bob Menendez has highlighted this ambiguity and proposed an amendment to fix it by making clear that the language only applies to defendant's attorney's fees. ${ }^{58}$ Absent a legislative fix, the Treasury or the IRS should clarify through regulation or rulemaking that section $162(\mathrm{q})(2)$ applies only to defendantside attorney's fees.

Another ambiguity in this new provision is how it relates to settlements of multiple claims. For example, assume that an employee alleges gender discrimination, sexual harassment, and wage and hour law violations, and the parties eventually settle for a lump sum. If a nondisclosure agreement is included, does the nondeduction rule apply to the entire settlement or only to the portion related to the sexual harassment? If the latter, will the parties' agreement that allocates all of the settlement to the other claims be respected by the IRS?

\section{F. Structured Settlements}

Lump sum settlements of taxable claims are taxed in the year in which payment is received. ${ }^{59}$ A lump sum settlement of tax-free claims (e.g.,

57. I.R.C. § 62(a)(20) (characterizing employment and civil rights plaintiff's attorney fees as above-the-line deductions).

58. Menendez Calls on GOP to Fix Its Tax Bill to Protect Victims of Workplace Sexual Misconduct, BoB Menendez For N.J. (Dec. 21, 2017), https:// www.menendez.senate.gov/news-and-events/press/menendez-calls-on-gop -to-fix-its-tax-bill-to-protect-victims-of-workplace-sexual-misconduct-.

59. Payment occurs when the plaintiff's lawyer receives the settlement funds on behalf of the attorney. To the extent the plaintiff is allowed a deduction for attorney's fees paid, it would be allowed in that same year. 
personal physical injury claims) is tax-free. ${ }^{60}$ However, if the tax-free cash received by the plaintiff is subsequently invested, the investment returns are taxed. For example, if the plaintiff invests her settlement in bonds or annuities, the return on those assets is taxed as interest under the normal tax rules. In other words, the exclusion for personal physical injury damages generally applies only to the receipt of the damages and not to subsequent investment returns on those damages.

Congress created an exception to this rule for certain structured settlements. In a structured settlement, the settlement agreement between the plaintiff and the defendant (or its insurer) calls for the defendant to make future specified payments to the plaintiff in exchange for a release of the plaintiff's claims. In virtually all structured settlements, the defendant then will immediately assign its obligation to make the specified future payments to a structured settlement company (SSC). In exchange for accepting the payment obligation, the SSC receives from the defendant a lump sum payment equal to the present value of the future payments owed to the plaintiff. The plaintiff, in turn, agrees to look only to the SSC for the future payments. ${ }^{61}$ The SSC then uses the lump sum payment that it receives from the defendant to purchase an annuity from a life insurance company. This annuity is called the funding asset, and it provides the SSC with the necessary liquidity to satisfy its payment obligations to the plaintiff. Often, the SSC simply directs the annuity issuer to pay the annuity benefits directly to the plaintiff. In almost all cases, the SSC used in a structured settlement is an affiliate of the life insurance company that issues the annuity that serves as the funding asset.

A typical structured settlement of a claim covered by the defendant's liability insurance policy is depicted in Figure 2. In a qualified structured settlement, the damages contributed into the structure represent tax-free damages, which are generally compensatory damages incurred in a personal physical injury case. The tax consequences of a qualified structured settlement are simple. The plaintiff does not report any income from either the funding or payouts of the structure; everything is tax-free. Physical injury plaintiffs only get this result by entering

60. As discussed above, certain components of otherwise tax-free recoveries (such as punitive damages and interest) are taxable.

61. In technical terms, the plaintiff grants the defendant (insurer) a novation with respect to its obligation to make future payments to her. 


\section{Figure 2:}

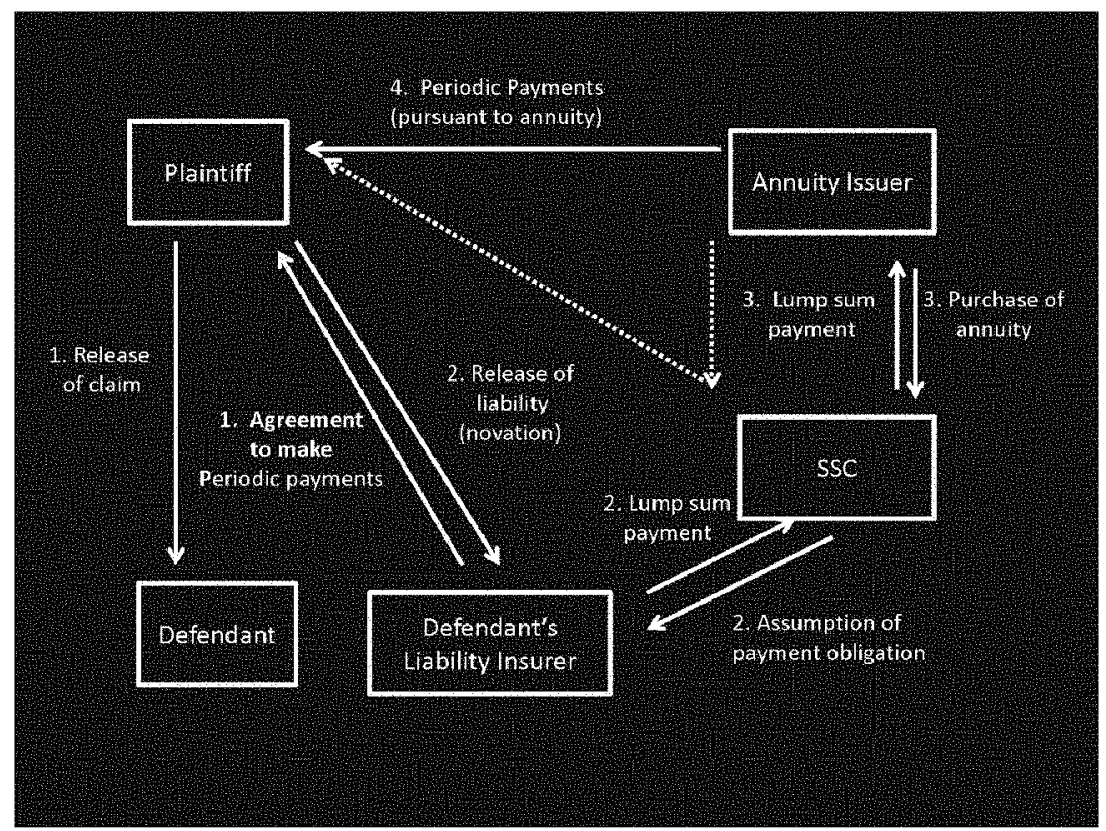

into a structure at the time of settlement. If the plaintiff receives a lump sum settlement and then immediately invests the cash in an annuity, the tax benefit is lost.

To illustrate the tax benefits of qualified structured settlements, consider the following alternative scenarios. In a lump sum settlement, the plaintiff receives $\$ 1,000,000$, all of which is tax-free, and invests the entire amount in an annuity that pays the plaintiff $\$ 136,000$ per year for ten years. ${ }^{62}$ In a qualified structured settlement, the plaintiff does not receive the lump sum; instead the defendant, through an SSC, buys the same annuity for the benefit of the plaintiff. Notice that the defendant is indifferent as between the two structures. In each case, the defendant pays $\$ 1,000,000$ and is released from any further liability. In addition, the defendant receives an immediate tax deduction of $\$ 1,000,000$.

62. If this is an "ordinary annuity" (first payment is due in one year, the second in two years, etc.) rather than an "annuity due" (first payment is due immediately, the second in one year, etc.), the discount rate is $6 \%$. It is assumed throughout this example that this is an ordinary annuity. 
Leaving aside taxes, the plaintiff is in a very similar position in both cases. ${ }^{63}$ The plaintiff will receive the same cash flow- $\$ 136,000$ per year for ten years - and is subject to the same risk of loss because the same annuity is used in each instance. However, the tax consequences to the plaintiff are quite different. In the lump sum situation, the plaintiff must pay tax on $\$ 36,000$ of each payment. ${ }^{64}$ No such tax applies in the structured settlement situation. Assuming the plaintiff's combined effective federal, state, and local tax rate is $25 \%$, the structured settlement saves the plaintiff $\$ 9,000$ in taxes each year for ten years. Assuming a $6 \%$ discount rate (the same rate implied by the annuity payouts), the present value of the tax savings is approximately $\$ 66,000$, or $6.6 \%$ of the lump sum settlement value. A higher marginal tax rate or a longer annuity would make the tax benefit even larger. If the plaintiff was subject to a $40 \%$ marginal tax rate, the structured settlement saves the plaintiff approximately $\$ 106,000$ in present value tax. And annuitizing the $\$ 1,000,000$ settlement over 30 (rather than ten) years would result in over $\$ 135,000$ of present value tax savings assuming a $25 \%$ marginal tax rate and over $\$ 216,000$ assuming a $40 \%$ rate.

Qualified structured settlements are not available for taxable awards or for taxable portions of otherwise tax-free awards. In those cases, nonqualified structured settlements are used. While not entirely free from doubt, the structured settlement industry believes that nonqualified structures successfully defer taxation from the time of settlement until the receipt of cash payments. If so, nonqualified structures represent a tax-efficient way for nonphysical injury plaintiffs to invest their recoveries in annuities.

To illustrate, assume that in an emotional distress claim not involving a physical injury or sickness, a plaintiff is offered a $\$ 1,000,000$

63. It is possible that for some purposes, such as bankruptcy law, there could be different consequences between the plaintiff owning an annuity outright and owning it through a structured settlement company. See, e.g., In re Alexander, 227 B.R. 658, 661 (Bankr. N.D. Tex. 1998) (holding that qualified structured settlement owned by the debtors was exempt from creditors).

64. See I.R.C. $\$ 72$. Note that section 72 , which provides the rules for taxing annuities, under-taxes annuitants on a present value basis by taxing interest earned in an annuity on a ratable basis instead of how the interest economically accrues. In the example above, the $\$ 280,000$ of total interest earned by the plaintiff is taxed $\$ 28,000$ per year for 10 years. In fact, the plaintiff earns about $\$ 60,000$ in the first year $(\$ 1,000,000$ principal times $6 \%$ ). 
lump sum settlement or, through a nonqualified structured settlement, an annuity that pays her $\$ 136,000$ per year for ten years. If the plaintiff is subject to a $25 \%$ combined federal, state, and local effective income tax rate, the plaintiff would be left with $\$ 750,000$ after taxes in the lump sum situation. In the nonqualified structured settlement scenario, the plaintiff would not be taxed until she receives the annual payments, which would be fully taxable. Accordingly, the plaintiff would be left with $\$ 102,000$ of the $\$ 136,000$ annual payments after paying the $25 \%$ tax. Thus, the choice is between receiving (on an after-tax basis) $\$ 750,000$ immediately or $\$ 102,000$ annually for ten years. Using a $6 \%$ discount rate (which is the rate that is implied by the annuity payout) and adjusting for the plaintiff's assumed $25 \%$ tax rate, the after-tax discount rate is $4.5 \%$. Applying that rate to the $\$ 102,000$ annual after-tax payments yields a present value of approximately $\$ 807,000$, which is $\$ 57,000$ greater than the after-tax of the lump sum. In short, while the lump sum payout has an after-tax value of $\$ 750,000$, the nonqualified structured settlement (which except for tax is identical) has an after-tax value of $\$ 807,000$.

In fact, both qualified and nonqualified structures effectively provide the same tax benefit - the complete exemption from tax of the investment return in the annuity. In qualified structures, both the principal (the lump sum value) and the yield are tax-free. In nonqualified structures, the principal is taxed, while the yield is effectively tax-free. ${ }^{65}$ If the plaintiff's marginal tax rate in the years in which she receives payments out of a nonqualified structure is lower than the marginal tax rate that would have applied to a lump sum payout, the plaintiff receives an additional "smoothing of income" benefit as well. In the example above, a large part of the $\$ 1,000,000$ lump sum settlement would have been subject to the highest marginal tax applicable to individuals, which is currently $37 \%$. On the other hand, the entire $\$ 136,000$ annual payments would likely be subject to a lower marginal tax rate.

65. In the example in the preceding paragraph, if the plaintiff had paid immediate tax on the $\$ 1,000,000$ settlement, she would be left with $\$ 750,000$ to invest. If she were able to invest on a tax-free basis, her rate of return would equal the pre-tax rate of $6 \%$. A 10 -year annuity earning $6 \%$ per year would pay out $\$ 102,000$, the same amount she receives after tax from the nonqualified structured settlement. This shows that, assuming constant tax rates, the tax benefit from a nonqualified structure is equivalent to a tax exemption for the investment yield. 
While qualified structures are statutorily allowed under the Code, nonqualified structures have been "blessed" only by a single private letter ruling issued in $2008 .{ }^{66} \mathrm{~A}$ private letter ruling is an IRS determination that provides the IRS's legal conclusion to a set of facts stipulated by a taxpayer. In the 2008 private letter ruling, the IRS concluded that a nonqualified structure yielded the tax results described above, namely that the nonphysical injured plaintiff realized income only when she received cash payments, not when the nonqualified structure was funded. However, private letter rulings are not binding on the IRS except with respect to the specific taxpayers to whom they are issued. ${ }^{67}$ Furthermore, the reasoning behind the private letter ruling and the principal case on which it appears to rely, Commissioner v. Childs, is questionable and has been the subject of criticism. ${ }^{68}$ (The Childs case, which involves a structured contingent attorney fee, is discussed in depth in Part V.A.) Despite the tax-law uncertainty surrounding nonqualified structures, they remain widely marketed by structured settlement companies and life insurance companies, which issue the underlying annuities.

Sometimes a plaintiff who receives a structured settlement, whether qualified or not, chooses to sell his rights in the structure to a third party. A sale of a qualified structure results in no gross income on the theory that the sales proceeds represent excludable damages. A sale of a nonqualified structure results in gross income equal to the amount of the sales proceeds because no exclusion applies. ${ }^{69}$ Under section 5891 , enacted by Congress in 2002, a sale of a qualified structure to a third party buyer will result in a significant excise tax payable by the buyer unless the sale is approved in advance by a court order ${ }^{70}$ The excise tax does not apply to the purchase of nonqualified structured settlements.

66. See P.L.R. 2008-36-019 (June 2, 2008).

67. See I.R.C. $\$ 6110(\mathrm{k})(3)$ (explaining that private letter rulings "may not be used or cited as precedent").

68. See Gregg D. Polsky \& Brant J. Hellwig, Taxing Structured Settlements, 51 B.C. L. REv. 39, 68-78 (2010) (criticizing the reasoning and legal analysis in Childs and the letter ruling).

69. The plaintiff in a nonqualified structure also has no tax basis in the structure because she has not paid any tax on the amounts remaining in the structure.

70. The amount of the excise tax is equal to $40 \%$ of the "factoring discount," which is the excess of the total undiscounted future payments owed to the plaintiff over the purchase of the structured settlement. I.R.C. 


\section{Reporting Obligations of Defendants and INSURANCE COMPANIES}

In general, defendants and insurers must file information reports to the IRS for amounts paid to plaintiffs and attorneys. With respect to payments to plaintiffs, defendants and insurers generally must report payments to plaintiffs on Form 1099-MISC (Box 3), except for amounts that are excluded from the plaintiff's gross income. ${ }^{71}$ Thus, in physical injury cases, no reporting is required unless a portion of the amount paid represents interest, punitive damages, or the recovery of previously deducted medical expenses. And, in nonphysical injury cases, the entire payment is reported except for any portion representing the recovery of prior medical expenses that were not previously deducted. In addition, under the Banks rule, in a taxable award situation, the gross settlement must be reported on the plaintiff's 1099-MISC even though some of the amount will be retained by the plaintiff's attorney pursuant to a contingent fee agreement. ${ }^{72}$

However, if the defendant is a current, former, or would-be employer of the plaintiff, any amounts paid that represent wages (generally back pay, front pay, or severance pay) must be reported on a Form W-2, rather than on a Form 1099-MISC. ${ }^{73}$ In addition, wage characterization triggers withholding obligations with respect to income taxes and employment taxes. ${ }^{74}$ Therefore, the plaintiff will not receive the gross amount of the wage portion of any settlement; instead, the plaintiff will receive an amount net of this withholding. If the plaintiff also receives a payment of non-wages, such as emotional distress

$\S 5891$ (a), (c)(4). To avoid the tax, the court order must determine, among other things, that the sale of the structured settlement "is in the best interest of the [plaintiff], taking into account the welfare and support of the [plaintiff's] dependents." I.R.C. § 5891(b)(2)(A)(ii).

71. See I.R.C. § 6041(a) (reporting not required if the payment is not made in connection with the payor's trade or business or if the amount paid is less than $\$ 600$ ); Reg. $\S 1.6041-1(\mathrm{c})$. Amounts allocated to interest should be reported on Form 1099-INT, Box 1 (if $\$ 600$ or greater).

72. See Reg. § 1.6041-1(f).

73. For discussion of the types of payments that are characterized as wages, see supra notes $37-41$ and accompanying text.

74. I.R.C. $\S \S 3101,3402$. It also triggers the employer's independent obligation to pay the employer's share of employment taxes. I.R.C. $\S 3111$. 
damages or reimbursement of attorney's fees, those are reported on Form 1099-MISC and are not subject to withholding.

The importance of proper allocations - whether between compensatory damages and punitive damages or interest in physical injury claims, or between wage payments and non-wage payments in employment-related claims - to plaintiffs was discussed above. Because of these reporting requirements, proper allocations are relevant to defendants and insurers as well. If allocations are incorrect, defendants or insurers could be liable for any resulting underpayment of tax by plaintiffs as well as for penalties. For this reason, defendants generally have little or no incentive to participate in aggressive allocations that, while beneficial to plaintiffs (at least if they are not audited), to them are generally all risk and no reward. ${ }^{75}$ The result is that well-advised defendants will err on the side of over-reporting income on Forms 1099-MISC and wages on Forms W-2. Reporting amounts on these forms are not dispositive with regard to the plaintiff's ultimate tax consequences because the plaintiff can report them differently on the plaintiff's own tax return. However, inconsistent reporting between the plaintiff's tax return and the defendant's information return will require an explanation and would probably trigger some degree of IRS scrutiny.

Payments to the plaintiff's attorney trigger another reporting obligation. In general, the gross amount paid to the attorney (by defendants or insurance companies) is reported in Box 14 of Form 1099MISC ${ }^{76}$ This reporting obligation exists even if the payment is also reported on another 1099-MISC with respect to the plaintiff or if the plaintiff's recovery is wholly tax-free. It is a completely independent reporting obligation.

In cases where one check, with plaintiff and attorney as joint payees, is delivered to the attorney, both obligations will be triggered ${ }^{77}$ (except to the extent any of the plaintiff's damages are excluded, in which case that portion will be exempt from Box 3 reporting with respect to

75. Because wage characterization triggers the employer-side portion of wage taxes, avoiding this characterization does benefit employers to some extent.

76. See Reg. $\S 1.6045-5$. Reporting is not required if the payment is not made in connection with the payor's trade or business or if the amount paid to the attorney is less than $\$ 600$. I.R.C. $\$ 6041$ (a)

77. See Reg. $\S 1.6045-5(f)$, Ex. 1. 
the plaintiff ${ }^{78}$ ). If two checks are delivered - one to the plaintiff and one to the attorney-both checks must be included on the plaintiff's 1099MISC (Box 3) ${ }^{79}$ but only the attorney's check must be included on the attorney's 1099-MISC (Box 14). ${ }^{80}$ This is consistent with the rule in Banks that requires the full settlement amount to be included in the plaintiff's gross income (with the attorney fee payment treated as a potential deduction).

\section{Tax Consequences for Defendants}

In general, a defendant can deduct payments or settlements made in connection with its business as ordinary and necessary trade or business expenses. ${ }^{81}$ This is true even for punitive damages, which are intended to punish the defendant for particularly egregious conduct. ${ }^{82}$ Because deducting punitive damages lessens the sting of those damages by having a portion of them effectively paid by the U.S. government in the form of a tax reduction, legislation has been proposed that would disallow deductions for punitive damages. ${ }^{83}$ To date, however, no such legislation has been enacted.

There are three departures from the general rule of deductibility of damages by business defendants. First, as already mentioned above, the so-called Harvey Weinstein rule disallows deductions for amounts paid in connection with sexual harassment or abuse if the parties have entered into a nondisclosure agreement. ${ }^{84}$ There is some uncertainty about how this new rule would be applied in cases where the sexual harassment or abuse allegations are accompanied by other

78. See Reg. $\$ 1.6045-5(f)$, Ex. 2.

79. This assumes that none of the amount represents wages, in which case a Form W-2 filing obligation will be triggered.

80. See Reg. § 1.6045-5(f), Ex. 3.

81. See I.R.C. $\$ 162$ (a).

82. See Rev. Rul. 80-211, 1980-2 C.B. 58 ("Amounts paid as punitive damages incurred by the taxpayer in the ordinary conduct of its business operations are deductible as an ordinary and necessary business expense under section 162 of the Code.").

83. See, e.g., U.S. Treas. Dep't, General Explanations of the Administration's Fiscal Year 2011 Revenue Proposals 95 (2010) (describing the Obama Administration's budget proposal to deny deductions for punitive damages paid).

84. I.R.C. $\S 162(\mathrm{q})$. 
allegations, such as gender discrimination and unlawful termination. Under one interpretation, the entire settlement would be nondeductible. Under another, only the portion properly allocable to the sexual harassment would be nondeductible. The latter interpretation arguably makes more conceptual sense, but it also results in very difficult allocation issues of the sort previously discussed. The defendant will have every incentive to allocate away from the sexual harassment claim, and the plaintiff will at best be indifferent to that allocation. ${ }^{85}$ It is likely that the government will issue guidance on this issue, as well as the issue of whether the denial of deductions for attorney's fees also applies to plaintiffs.

Second, payments made "to, or at the direction of, a government or governmental entity in relation to the violation of any law or the investigation or inquiry by such government or entity into the potential violation of any law" are generally nondeductible. ${ }^{86}$ However, this rule does not apply to any amount paid "by reason of any order of a court in a suit in which no government or governmental entity is a party." ${ }^{87}$ In addition, the rule does not apply to the extent the payor establishes that an amount constitutes restitution and is identified as a restitution payment in the court order or settlement agreement. ${ }^{88}$

85. As discussed above, the new rule could arguably be interpreted to disallow even the plaintiff's attorney's fees. See supra note 57 and accompanying text. If so, an allocation away from sexual harassment could affirmatively serve the plaintiff's tax interests as well.

86. I.R.C. $\S 162$ (f)(1). Prior to the 2017 Tax Act, this rule was narrower. Historically, payments made to governments were nondeductible. The 2017 Tax Act extends this rule to payments made "to, or at the direction of a government or governmental agency" if the government or governmental agency is a party in the litigation. I.R.C. $\S 162(f)(1),(3)$.

87. I.R.C. $\$ 162(f)(3)$. For purposes of section 162(f), certain nongovernment entities are treated as government entities. I.R.C. $\S 162(\mathrm{f})(5)$.

88. I.R.C. $\$ 162(f)(2)(A)$. Prior to the 2017 Tax Act, regardless of the language in the settlement agreement, a defendant could try to argue that payments made to the government were non-punitive (e.g., compensatory or restitution-type payments) in nature in order to preserve deductibility. See, e.g., Fresenius Med. Care Holdings, Inc. v. United States, 763 F.3d 64, 69 (1st Cir. 2014). The 2017 Tax Act now requires that the payment be specifically identified as restitution (or payments to "come into compliance with any law") in the settlement or court order to be deductible. $\S 162(\mathrm{f})(2)(\mathrm{A})(\mathrm{i})(\mathrm{II})$. In addition, amounts paid by defendants as reimbursement for governmental investigation expenses are no longer deductible. I.R.C. $\S 162(f)(2)(B)$. New Code 
Finally, in cases where a taxpayer is convicted of, or pleads guilty or nolo contendere to, a violation of antitrust laws, the taxpayer may not deduct two-thirds of a treble damages award or settlement. ${ }^{89}$

\section{Admissibility of Tax Evidence}

In some cases, one or both parties may desire to introduce evidence of tax consequences. For example, a defendant in a physical personal injury case may try to introduce evidence that the plaintiff's award of lost wages would be tax-free, even though if the plaintiff had earned those wages in due course, they would have been subject to income and employment taxes. If successfully introduced, this argument could drive down the amount of wages awarded by the factfinder. This is because the factfinder would presumably award after-tax, rather the pre-tax, wages.

\section{A. Tax Evidence Sought To Be Introduced by Defendants}

The situation above-where the defendant attempts to introduce the fact that some or all of a plaintiff's award will be tax-free-is the most common scenario where tax evidence has been attempted to be introduced. For instance, assume that a physically injured plaintiff suffers lost wages of $\$ 100,000$ and that, if she had earned those wages in due course, she would be left with only $\$ 60,000$ after paying federal, state, and local taxes. Can the defendant introduce this tax effect to the factfinder so as to reduce its liability for lost wages from $\$ 100,000$ to $\$ 60,000$ ?

The majority of jurisdictions in the United States have determined this type of evidence to be inadmissible, ${ }^{90}$ and the Second Restatement of Torts generally concurs. ${ }^{91}$ Courts justify this rule in two ways. First, allowing the defendant to use the plaintiff's tax exclusion to reduce its exposure would shift the benefit of section 104(a)(2)'s exclusion from the plaintiff, who formally receives the exclusion, to the defendant, who

section $6050 \mathrm{X}$ imposes reporting requirements on governmental entities (and entities treated as governmental entities under section 162(f)(5)) to ensure compliance with these rules.

89. I.R.C. \& $162(\mathrm{~g})$.

90. See John E. Theuman, Annotation, Propriety of Taking Income Tax into Consideration in Fixing Damages in Personal Injury or Death Action, 16 A.L.R. 4th 589, 594-99 (1982).

91. Restatement (Second) of Torts $§ 914$ A (Am. Law Inst. 1979). 
would pay a lower amount of damages due to the existence of the exclusion. On the other hand, disallowing the tax evidence would overcompensate plaintiffs because they walk away with the entire pre-tax award when they would have been left with a smaller after-tax amount had the tort not occurred. The section 104(a)(2) exclusion thus puts courts in the position of choosing between under-deterring defendants or overcompensating plaintiffs. ${ }^{92}$ Faced with this dilemma, courts have generally chosen the latter, erring on the side of the sympathetic victim over the tortfeasor. ${ }^{93}$

Second, courts have noted that evidence regarding future tax consequences can be quite speculative. ${ }^{94}$ This concern is implicated by front pay awards. To adjust awards for tax effects, factfinders would have to make their best guesses as to what the tax rates (and potentially other tax rules) will be in the future, as well as the future income levels of plaintiffs. Factfinders, however, must make their best guesses on many issues in the damages context, including on the plaintiff's future employment, health, medical expenditures, and lifespan, as well as on future interest rates and inflation. In this context, the speculation involved in tax-effecting front pay awards does not seem at all exceptional.

While the majority rule is to disallow the introduction of evidence relating to a plaintiff's special tax breaks, some courts have held otherwise. The most famous case to buck the trend is the U.S. Supreme Court's decision in Norfolk \& Western Railway Co. v. Liepelt..$^{95}$ That case involved a wrongful death award under the Federal Employers' Liability Act (FELA). Under the relevant part of FELA, an estate may receive "the damages... [that] flow from the deprivation of the pecuniary

92. See Joseph M. Dodge, Taxes and Torts, 77 Cornell L. Rev. 143, 146 (1992) (noting that section 104(a)(2) "forces states to choose between overcompensating plaintiffs and potentially underburdening defendants" (footnote omitted)).

93. See, e.g., Dixie Feed \& Seed Co. v. Byrd, 376 S.W.2d 745, 749 (Ct. App. Tenn. 1963) (explaining that "to deduct the anticipated tax saving from the recovery would nullify the tax benefit conferred by Congress in expressly exempting damages for personal injuries").

94. See, e.g., id. (noting that introducing tax evidence "would inject into the already difficult and complicated computations of [lost wages] damages factors which change from time to time, such as the rate of taxation and the number of plaintiff's exemptions, and allow juries to indulge in speculation and conjecture in arriving at the amount to be deducted").

95. Norfolk \& W. Ry. Co. v. Liepelt, 444 U.S. 490 (1980). 
benefits which the [decedent's] beneficiaries might have reasonably received." ${ }^{96}$ The Court held that this language requires that after-tax, rather than pre-tax, earnings be considered because after-tax income "provides the only realistic measure of [the decedent's ability] to support his family." tor in calculating the monetary loss suffered by his dependents when he dies." ${ }^{98}$ This conclusion has been followed by lower federal courts in other cases involving federal causes of action for lost earnings. ${ }^{99}$

\title{
B. Tax Evidence Sought To Be Introduced by Plaintiffs
}

\section{Adverse Tax Consequences of Recovery}

In employment discrimination cases, plaintiffs have successfully argued that their awards should be augmented or "grossed up" to neutralize adverse tax consequences that would otherwise be borne by them. The most common adverse tax effect is due to the bunching of several years' worth of wages into the year of settlement, which causes part or all of the wage award to be subject to unusually high marginal tax rates. Consider, for example, a plaintiff who, due to unlawful discrimination, has been underpaid $\$ 20,000$ for the past ten years. Had the $\$ 20,000$ extra pay been earned in due course, the pay would have been subject to a combined federal and state marginal income tax rate of $25 \%$. However, when the $\$ 200,000$ is received in the year of settlement, only $\$ 20,000$ is taxed at a $25 \%$ rate and the remaining $\$ 180,000$ is taxed at a $30 \%$ rate. In that case, the plaintiff suffers an extra $\$ 9,000$ tax burden. ${ }^{100}$ An augmented award is necessary to fully restore the plaintiff. In addition,

\author{
96. Id. at 493 . \\ 97. Id. \\ 98. Id. at 494 . \\ 99. See, e.g., Kirchgessner v. United States, 958 F.2d 158, 161
} (6th Cir. 1992) (plaintiff's tax consequences may be introduced under the Federal Tort Claims Act); Davis v. Little, 851 F.2d 605, 611 (2d Cir. 1988) (plaintiff's tax consequences may be introduced in claims arising under 42 U.S.C. $\S 1983$ ); Fanetti v. Hellenic Lines Ltd., 678 F.2d 424, 431 (2d Cir. 1982) (stating that the rule in Liepelt applies "at least to all federal law claims for future lost wages").

100. $\$ 180,000 \times(.30-.25)=\$ 9,000$. For simplicity, this example ignores the time-value of money. 
because the gross up is itself taxable, the plaintiff would have to receive an augmentation of approximately $\$ 13,000 .{ }^{101}$

Nearly all federal courts that have considered this issue in the employment discrimination context have held that tax gross ups are permissible due to the legislative mandate in federal anti-discrimination laws to make the victim whole. ${ }^{102}$ For example, in a recent Title VII case, the Ninth Circuit concluded that the lower court erred by summarily denying the plaintiff's request for a tax gross up to offset the adverse effect of bunching back-pay amounts into a lump sum judgment. ${ }^{103}$ In so holding, the court emphasized that, while tax gross ups are permissible in Title VII cases, they are not required in every case. Instead, trial courts can use their discretion to determine whether to award a gross up in a particular case. ${ }^{104}$

Some state courts have similarly permitted tax gross ups in discrimination cases. For instance, the Washington Supreme Court found that the Washington Law Against Discrimination permitted a tax gross

101. The plaintiff would have to pay a tax of $30 \%$ on the $\$ 13,000$, leaving the plaintiff with $\$ 9,100$ to offset the adverse tax consequences. To calculate the gross up, the adverse tax consequences (in this example, $\$ 9,000$ ) is divided by the excess of one over the plaintiff's marginal tax rate (here $30 \%$ ).

102. See EEOC v. N. Star Hosp., Inc., 777 F.3d 898, 903-04 (7th Cir. 2015); Eshelman v. Agere Sys., Inc., 554 F.3d 426, 440-43 (3d Cir. 2009); Sears v. Atchison, Topeka \& Santa Fe Ry., Co., 749 F.2d 1451, 1456-57 (10th Cir. 1984); O'Neill v. Sears, Roebuck \& Co., 108 F. Supp. 2d 443, 446-48 (E.D. Pa. 2000); Arneson v. Sullivan, 958 F. Supp. 443, 446-47 (E.D. Mo. 1996), rev'd in part, 128 F.3d 1243 (8th Cir. 1997). One federal appellate case upheld the trial court's denial of an employment plaintiff's request for a gross up based on a perceived lack of authority for such a gross up even though the case was decided a decade after Sears, 749 F.2d. at 1451. Dashnaw v. Pena, 12 F.3d 1112 (D.C. Cir. 1994). However, this decision was a per curium opinion; there was no analysis; and it ignored the earlier Tenth Circuit's decision in Sears. See Clemens v. Centurylink Inc., 874 F.3d 1113 (9th Cir. 2017) (criticizing and declining to follow Dashnaw for these reasons and concluding that a gross up is permissible in a Title VII case).

103. Clemens, 874 F.3d at 1115-17.

104. See id. at 1117 ("There may be many cases where a gross up is not appropriate for a variety of reasons, such as the difficulty in determining the proper gross up or the negligibility of the amount at issue. In any case, the party seeking relief will bear the burden of showing an income-tax disparity and justifying any adjustment."). 
up for back pay and front pay awards in a gender discrimination claim. ${ }^{105}$ And at least one federal district court has allowed a tax gross up with regard to back pay and future economic damages awards in a section 1983 case. . $^{106}$

All of these cases allowed gross ups with respect to back pay and front pay awards. The logic behind these gross ups is that any excessive taxation of those components (relative to how they would have been taxed had they been earned in due course) should be borne by defendants, not plaintiffs. A few plaintiffs have argued that gross ups should also be applied to other types of damages, such as those for emotional pain and anguish. These arguments, however, have not been successful. For example, the Washington Supreme Court, which had previously allowed gross ups for lost wages under the state's anti-discrimination law, declined to gross up a plaintiff's award for emotional distress under the same state law. ${ }^{107}$ The court reasoned that, because "Congress explicitly decided that noneconomic damages were to be taxable when they are attributable to nonphysical injury and Congress placed this tax

105. Blaney v. Int'1 Ass'n of Machinists \& Aerospace Workers, 87 P.3d 757 (Wash. 2004); see also Ferrante v. Sciaretta, 839 A.2d 993 (N.J. Super. Ct. Law Div. 2003). The underlying tax problem in both Blaney and Ferrante did not involve bunching (which was the problem in the federal gross up cases), but rather resulted from the alternative minimum tax rule's interaction with the plaintiff's deduction for attorney's fees. While this specific tax problem was solved by Congress's enactment of section 62(a)(20), these cases stand for the broader proposition that tax gross ups are permissible, regardless of the origin of the tax problem. See Quinlan v. Curtiss-Wright Corp., No. L-8976-03, 2007 WL 4239957 (N.J. Super. Ct. Law Div. June 15, 2007) (allowing evidence on adverse tax consequences to be introduced in employment discrimination case to calculate gross up).

106. Humann v. City of Edmonds, No. 2:13-cv-00101, 2015 WL 3539569 (W.D. Wash. June 3, 2015).

107. Van Pham v. City of Seattle, 151 P.3d 976 (Wash. 2007); see also Gibson v. City of Paterson, 199 Fed. Appx. 133, (3d Cir. 2006) (rejecting gross up for emotional distress and mental anguish damages in federal civil rights case); Graham v. Brennan, No. 1:16-cv-00242-CL, 2017 WL 5505800 (D. Or. Sept. 26, 2017) (rejecting gross up for non-wage portion of award in federal discrimination case); O'Neill, $108 \mathrm{~F}$. Supp. 2d at 446 (rejecting gross up for non-wage portions, while allowing gross up for back pay and front pay). 
burden on the plaintiff," "[s]hifting the tax burden on these awards entirely to the defendant simply goes too far."'108

\section{Defendant's Tax Benefits from Paying Punitive Damages}

Typically, when plaintiffs try to introduce tax evidence, it is to attempt to augment their recoveries so as to counteract their own adverse tax consequences, as discussed immediately above. Plaintiffs may also attempt to introduce tax evidence regarding the defendant's favorable tax consequences from paying damages. For instance, because punitive damages incurred by businesses are deductible as business expenses, ${ }^{109}$ plaintiffs alleging punitive damages could try to introduce this tax effect to support a higher award. ${ }^{110}$

Jurors assess punitive damages in an amount that they believe will best "punish" the defendant. But, due to the tax effect, business defendants will not be punished to the degree that the jury intends. For example, assume that a jury determines that, based on the egregiousness of the defendant's conduct and its net worth, the defendant should pay $\$ 10,000,000$ in punitive damages. If the defendant is subject to a

108. Van Pham, 151 P.3d at 980-81 (emphasis in original).

109. See I.R.C. § 162(a) (allowing a deduction for ordinary and necessary expenses incurred in carrying on a trade or business); Rev. Rul. 80-211, 1980-2 C.B. 57, 58 (explaining that punitive damages incurred in connection with a taxpayer's trade or business are deductible under section 162). As discussed above, there are some situations where certain amounts paid by defendants in narrow situations are not deductible. See supra notes 84-89 and accompanying text. First, under the Harvey Weinstein rule, damages (and attorney's fees) paid with respect to sexual abuse/harassment claims are not deductible if the parties execute a nondisclosure agreement. I.R.C. § 162(q). Second, payments made "to, or at the direction of, a government or governmental entity in relation to the violation of any law or the investigation or inquiry by such government or entity into the potential violation of any law" are generally nondeductible. I.R.C. $\$ 162(f)(1)$. Finally, in certain antitrust cases, two-thirds of a treble damages award are nondeductible. I.R.C. $\$ 162(\mathrm{~g})$. Outside of these three contexts, punitive damages (as well as compensatory damages) are deductible by business defendants.

110. See generally Gregg D. Polsky \& Dan Markel, Taxing Punitive Damages, 96 VA. L. Rev. 1295 (2010). 
combined effective federal and state tax rate of $25 \%,{ }^{111}$ the after-tax cost of the punitive damages is only $\$ 7,500,000$, far less than what the jury intended.

The Obama Administration proposed to fix this underpunishment problem by amending the Code to disallow deductions for punitive damages. ${ }^{112}$ While part of the Obama Administration's budget for several years, the fix was never enacted into law. Because punitive damages remain deductible by business defendants, plaintiffs should seek to introduce evidence of this deductibility in punitive damage cases. Plaintiffs would argue, either to a jury or judge, that the punitive damage award should be grossed up to account for the defendant's ability to deduct it. To gross up an award, the intended punishment amount simply needs to be divided by the excess of one over the defendant's effective marginal tax rate. Thus, in the example above, $\$ 10,000,000$ would be divided by $.75(1-.25)$, which yields a punitive damage award of $\$ 13,333,333$. $^{113}$ The prospect of such a grossed up award should increase pre-trial settlement amounts.

Defendants might argue that this approach is unfair to defendants because the plaintiff's tax consequences are generally inadmissible. ${ }^{114}$ However, as explained above, there are good reasons to exclude evidence of the plaintiff's circumstances, namely the fact that to do so allows a tax benefit intended by Congress to benefit plaintiffs to be co-opted by

111. This is roughly the marginal tax rate to which a typical corporate defendant would be subject. The federal corporate rate is currently $21 \%$ (I.R.C. \$ 11), and state corporate tax rates are often in the neighborhood of 6\%. Morgan Scarboro, State Corporate Income Tax Rates and Brackets for 2018, TAx Found. (Feb. 7, 2018), https://taxfoundation.org/state-corporate -income-tax-rates-brackets-2018/. Because state corporate taxes are deductible for federal income tax purposes, a $6 \%$ corporate tax rate translates to a $4.74 \%(6 \% \times .79)$ effective state tax rate and would result in a $25.74 \%$ combined effective tax rate.

112. See, e.g., U.S. Treas. DeP'T, supra note 83, at 95 (describing the Obama Administration's budget proposal to deny deductions for punitive damages paid).

113. When the defendant pays $\$ 13,333,333$, the deduction saves the defendant $\$ 3,333,333(\$ 13,333,333 \times .25)$ in federal and state income taxes. The result is an after-tax punishment of $\$ 10,000,000$.

114. See supra notes 90-94 and accompanying text (discussing majority rule that plaintiffs' tax evidence is not admissible). 
defendants. Defendants could also argue that tax evidence is unduly complex or speculative, but when considered in the context of other complex and speculative decisions that must routinely be made by factfinders, this argument does not appear to be persuasive. ${ }^{115}$

The potential introduction of tax evidence in punitive damages cases also has implications for the constitutional review of punitive damages. Consider the case of State Farm v. Campbell, where the Supreme Court set aside a jury's $\$ 145$ million punitive damages award because the amount of the award violated the Due Process Clause of the Constitution's Fourteenth Amendment. ${ }^{116}$ In so doing, the Court announced that "few awards exceeding a single-digit ratio between punitive and compensatory damages, to a significant degree, will satisfy due process." 117 Importantly, nothing in the opinion reveals that the Court (or any lower court) was aware of the fact that the defendant, a large insurance company, would have been able to deduct the punitive damages at issue. Campbell's lawyers should have enlightened the trial court as to the fact and effect of such a deduction, but this would have likely been fruitless in this particular case because the Court found even the nongrossed up amount excessive.

Nevertheless, the State Farm case seems to leave open the question of whether, in assessing the constitutionality of punitive damage awards, courts should focus on the pre-tax amount of the award or its after-tax cost. For example, in applying the single-digit multiplier presumption, should courts compare the compensatory damages to the nominal (i.e., pre-tax) amount of the award or to the actual (i.e., aftertax) cost of the award? Business defendants would clearly prefer to use the nominal amount of the award to keep the presumptive ceiling where it is. To accomplish this, defendants might point to the language of State Farm, which focuses on the nominal amount of the award. ${ }^{118}$

This argument, however, is not a very good one because the Court in State Farm never addressed the defendant's tax consequences. Indeed, it likely never realized that the after-tax cost of the award might

115. For a full discussion of the argument in support of tax gross ups for punitive damages and the counter-arguments against, see Polsky \& Markel, supra note 110, at 1307-22.

116. State Farm Mut. Auto. Ins. Co. v. Campbell, 538 U.S. 408, $417-29$ (2003).

117. Id. at 425 .

118. See id. at 429 . 
have differed substantially from the nominal award. Even if the Court were generally aware of the fact of deductibility, no evidence of the deduction's value to the defendant was presented during the course of litigation. Furthermore, because the majority in State Farm found its rejection of the 145:1 ratio of nominal punitive damages to compensatory damages "neither close nor difficult," 119 even if the Court were inherently aware of tax consequences, a tax adjustment likely would have made no difference to the disposition of that particular case. ${ }^{120}$ Thus, any suggestion that State Farm itself addressed the constitutional tax-awareness issue places far too much weight on mere dicta.

The Court has interpreted the Due Process Clause to prohibit "grossly excessive" punitive damage awards, ${ }^{121}$ and the application of the single digit ratio presumption is intended to help courts assess when punitive damages awards become unconstitutionally arbitrary deprivations of property. Because the due process analysis focuses on the amount of property deprivation, courts should focus on the after-tax cost of the award because that is the amount that represents the real financial setback borne by the defendant. To focus on nominal or pre-tax amounts, which in some cases will equal or closely approximate after-tax costs ${ }^{122}$ and in other cases will not, would introduce unnecessary arbitrariness into the process. To more accurately assess the punitive force of damages on defendant, courts applying the due process analysis should focus on the after-tax costs to the defendant.

This argument provides another incentive for trial lawyers to introduce tax evidence in punitive damages trials against business defendants. Not only should tax-aware factfinders, all else being equal, render higher punitive damage verdicts, but tax-aware judges should raise the ceiling on constitutionally permissible awards. ${ }^{123}$

119. Id. at 418; see id. 425-26.

120. For example, even a $50 \%$ effective marginal rate would only have brought the ratio down to $72.5: 1$, still well higher than the $10: 1$ standard that the Court articulated.

121. State Farm, 538 U.S. at 416.

122. If punitive damages relate to the defendant's personal conduct (as opposed to the taxpayer's business activities) or if the defendant is taxexempt (such as a charitable, educational, religious, or other 501(c)(3) organization), the pre-tax award will be the same as the after-tax cost because the defendant would receive no tax benefit from paying the award.

123. State Farm also reiterates that reviewing courts should compare the amount of the punitive damages award to the amount of "civil 


\section{Personal Tax Issues of Trial Lawyers}

This Article turns now to the personal tax issues of trial lawyers themselves. This Part addresses tax issues that are unique to trial lawyers. Part VI will then describe important tax law changes in the 2017 Tax Act that, while broadly applicable, could be of significant interest to trial lawyers.

\section{A. Structured Attorney Fees}

Structured settlements of plaintiff recoveries were previously discussed in Part I.F. In qualified structures, which are only available in physical injury and physical sickness cases, cash payments out of the structure are entirely tax-free. ${ }^{124}$ In nonqualified structures, which are used in other settlements, the plaintiff realizes taxable income only when cash payments are received.

Trial lawyers also sometimes structure their contingent fees. In an attorney fee structure, instead of receiving the entire attorney fee in cash upon settlement of the case, the attorney invests some or all of the fee in an annuity that will pay the fee (plus an investment return) over time. Attorneys who structure their fees take the tax position that there is no immediate taxable income upon the funding of the structure. ${ }^{125}$ Instead, income is realized by the attorney only as cash is paid out of the structure. Thus, the intended tax results are similar to a plaintiff's in a nonqualified structure. There are two benefits from this tax treatment. First, the attorney's income tax liability with respect to the structured fee is deferred, from the time of settlement until the receipt of cash,

penalties authorized or imposed in comparable cases." State Farm, 538 U.S. at 428 (quoting BMW of N. Am., Inc. v. Gore, 517 U.S. 559, 575 (1996)). In order to make an appropriate apples-to-apples comparison, courts should compare the after-tax costs of such penalties. As previously discussed, civil penalties paid to, or at the direction of, governmental entities are generally nondeductible, so these nominal amounts of nondeductible civil penalties should be compared to the tax-adjusted amount of deductible punitive damages.

124. Taxable components of awards that are otherwise tax-free under section 104(a)(2) cannot be part of a qualified structure. These components can, however, be placed in a nonqualified structure.

125. The funding of the structure is the purchase of the annuity that will make payments to the attorney in the future. 
allowing the attorney to invest amounts that otherwise would have been paid to the government. Second, a large contingent fee can cause the lawyer to be in an unusually high tax bracket in the year in which the fee was earned. Structured attorney fees allow the lawyer to "smooth" the large fee over a period of time, reducing the marginal tax rate that will apply to the income. These two benefits - tax deferral and income smoothing - can be extremely valuable.

While qualified structured settlements have been legislatively blessed in the Code, nonqualified structured settlements and attorney fee structures are based on shakier legal ground. Proponents of these structures rely on an anomalous Tax Court decision in Childs v. Commissioner. ${ }^{126}$ The taxpayers in that case were trial lawyers who had executed a contingent fee agreement with a personal physical injury client. The case was eventually settled, with both the client and the attorneys structuring their respective litigation recoveries. Specifically, the defendant's insurer agreed to make certain future payments to the client and to the attorneys, and the insurer then assigned these payment obligations to a structured settlement company. The structured settlement company thereafter purchased an annuity to fund its assumed payment obligations. ${ }^{127}$ The Childs case addressed the tax consequences of the arrangement to the attorneys. ${ }^{128}$ The precise issue was whether the attorneys recognized income upon the creation of the structured arrangement or, as the attorneys argued, only as the scheduled cash payments were received.

The Tax Court sided with the attorneys, concluding that they were required to report gross income only as they received payments out of the structured settlement. The court found that the obligation of the structured settlement company to make future payments to the attorneys

126. Childs v. Comm'r, 103 T.C. 634 (1994), aff'd, 89 F.3d 856 (11th Cir. 1996).

127. Id. at $639-42$. The attorneys were named as the annuitants under the annuity, and their respective estates were designated as contingent beneficiaries of their share. However, the structured settlement company remained the owner of the annuity.

128. The tax consequences to the plaintiff were clear because the plaintiff's structure constituted a qualified structured settlement, which is legislatively sanctioned. Accordingly, the plaintiff would have been able to exclude all of the periodic payments from gross income. 
constituted an "unfunded and unsecured promise to pay," which is generally not taxable when received by individual taxpayers. ${ }^{129}$ However, this conclusion has been criticized by commentators because the unfunded and unsecured promise to pay rule traditionally applied only to second-party promises, not to third-party promises. Under longstanding caselaw, third-party promises were immediately taxed. ${ }^{130}$ Second-party promises are promises to pay made by the recipient of the service provider's services, while third-party promises are promises made by any other person. In the Childs case, the second-party was the client of the attorneys; the client was the person for whom the attorneys provided the services for which they were being paid. The promise to pay by the structured settlement company was therefore a third-party promise, and under well-established doctrine should have been immediately taxed. However, the Childs opinion never addressed the secondparty versus third-party promise issue, so it did not even attempt to distinguish the facts from those in other third-party promise cases. For this reason, the Childs opinion has been criticized by commentators. ${ }^{131}$ The IRS has noted this criticism, ${ }^{132}$ though it has not formally

129. Childs, 103 T.C. at 649. Individual taxpayers typically report their income using the cash receipts and disbursements method of accounting, under which an unfunded and unsecured promise to pay is not taxable. See Reg. $§ 1.83-3(\mathrm{e})$.

130. See, e.g., Sproull v. Commissioner, 16 T.C. 244 (1951), aff'd, 194 F.2d 541 (6th Cir. 1952).

131. See Gordon T. Butler, Economic Benefit: Formulating a Workable Theory of Income Recognition, 27 Seton HaLl L. Rev. 70, 118-19 (1996) (contending that the holding in Childs is erroneous because the court failed to recognize that the payment obligation was issued by a third party); Polsky \& Hellwig, supra note 68, at 1131-35 (same criticism as Butler); Gregg D. Polsky \& Brant J. Hellwig, Close the Yield Exemption Loophole Created by Childs, 123 TAx Notes 1141 (June 1, 2009) [hereinafter Polsky \& Hellwig, Loophole]. For revenue rulings reaching a contrary holding in analogous factual circumstances, see Rev. Rul. 77-420, 1977-2 C.B. 172; Rev. Rul. 69-50, 1969-1 C.B. 140. Nonetheless, additional authority for the Tax Court's flawed interpretation of section 83 in Childs can be found in Minor v. United States, 772 F.2d 1472 (9th Cir. 1985). For discussion and criticism of the Ninth Circuit's decision in Minor, see Polsky \& Hellwig, supra note 68, at 1136-39.

132. See IRS Coordinated Issue Paper, Transfer or Sale of Compensatory Options or Restricted Stock to Related Persons n.9 (October 14, 2004). 
repudiated the holding despite calls to do so. ${ }^{133}$ And the Tax Court decision in Childs was affirmed by the Eleventh Circuit, albeit in an unpublished per curiam opinion without any discussion. ${ }^{134}$

Childs, therefore, remains "good law," though it remains possible that in the future the IRS will, through regulation or ruling, announce its disagreement with it or will challenge attorneys residing outside the Eleventh Circuit. The Childs case essentially creates a "super-IRA" savings vehicle just for trial lawyers. Traditional IRAs allow taxpayers to invest a limited amount of pre-tax dollars in a retirement account. These pre-tax dollars grow tax-free inside the IRA. When amounts are withdrawn, they are taxed as ordinary income. Structured attorney fees are similar to IRAs but are even better. While IRAs have strict annual contribution limits, penalties for pre-retirement withdrawals, and required minimum distributions after age 70 , these rules do not apply to structured attorney fee arrangements. ${ }^{135}$ Structured attorney fees provide all the tax benefits of IRAs without any of the restrictions or limitations, and they are available only to the personal injury plaintiff's bar. ${ }^{136}$

As previously mentioned, the Childs holding and reasoning also supports the intended tax treatment of nonqualified structured settlements. ${ }^{137}$ Nonqualified structures are structured settlements entered into by plaintiffs who receive taxable awards (or taxable components of otherwise tax-free awards). While qualified structures have been

133. See Polsky \& Hellwig, Loophole, supra note 131.

134. See Childs v. Comm'r, 89 F.3d 856 (11th Cir. 1996).

135. Amounts invested in structured settlements can be "withdrawn" before retirement age either by providing for cash payments to be received before then or by selling the structured settlement obligation for cash to a third-party buyer.

136. Structured fee arrangements also compare extremely favorably to employer-provided qualified plans, such as $401(\mathrm{k})$ plans. Both allow for pre-tax contributions and tax-free compounding. However, structured fee arrangements, unlike qualified plans, allow for unlimited contributions and penalty-free early withdrawals and are not subject to the required minimum distribution rules. In addition, unlike qualified plans, structured fee arrangements may be created for the exclusive benefit of highly compensated employees. For this reasons, one lawyer has described the structured fee arrangement as "a personal discriminatory retirement plan." Richard B. Risk Jr., Are You Income Tax Deferring Your Fee? (2006), http://www.risklawfirm.com/files /Formatted_Articles/AreYouIncomeTaxDeferringYourFee.doc.

137. See supra notes 66-68 and accompanying text. 
legislatively sanctioned, the tax consequences of nonqualified structures are less clear. A 2008 private letter ruling determined that a plaintiff who entered into a nonqualified structure was taxed only as the plaintiff received cash payments out of the structure, a result that is consistent with Childs, which is cited in the ruling. ${ }^{138}$ Though a private letter ruling is binding on the IRS only with respect to the taxpayer who requested it, ${ }^{139}$ the ruling and the holding in Childs has convinced the structured settlement industry that, while not entirely free from doubt due to the sloppy analysis by the Tax Court in Childs, nonqualified structures will likely be taxable to plaintiffs only as they receive cash payments.

Attorney fee structures could be used to help certain plaintiffs circumvent the denial of miscellaneous itemized deductions that was included in the 2017 Tax Act. ${ }^{140}$ These deductions are scheduled to spring back to life in 2026. ${ }^{141}$ Attorney fee structures may be used to defer the deemed payment of attorney fees until 2026 or later. ${ }^{142}$ Under the theory of Childs, attorney fee structures are deemed unfunded and unsecured promises to pay, which generally result in deductions to the recipient of the payee's services at the time of payment (not at the time the promise to pay is earned). ${ }^{143}$ If so, attorney fee structures that delay payments beyond 2025 could preserve deductions that would otherwise be lost. There are several caveats that must be considered before implementing this strategy. First, it must be remembered that the miscellaneous

138. See supra note 66.

139. See supra note 67.

140. See supra notes 53-56 and accompanying text.

141. See supra note 54.

142. Attorney fee structures could be stand-alone structure (where the plaintiff receives the full award in the year of settlement) or can be combined with the plaintiff's structured settlement.

143. See I.R.C. \$ 83(h). Under the theory of Banks, any payments to the attorney pursuant to an attorney fee structure are deemed to flow through the plaintiff, who must report the payment in gross income and could (to the extent allowed by law) claim the amount as a deduction. Combined with the Childs reasoning, this means that as payments are made to the attorney, the plaintiff realizes gross income and a deduction equal to the amount of the attorney fee payment in that year. Thus, for example, if an attorney receives a $\$ 100,000$ payment from a fee structure in 2026 , the plaintiff must include the $\$ 100,000$ in gross income and would receive a $\$ 100,000$ miscellaneous itemized deduction in that year (assuming that the award in question is not excluded under section 104(a)(2)). 
itemized deduction statute could be amended by Congress (either to fix the denial of miscellaneous itemized deductions, which would make the deferral of attorney fees unnecessary, or to extend the denial, which could make deferral ineffective). Second, the historical limitations on miscellaneous itemized deductions, which also are scheduled to spring back to life, could dramatically impair the tax benefits actually realized by the plaintiff with respect to post-2025 attorney fee payments. The plaintiff's unique tax situation must be carefully considered to determine the effect of those limitations. Third, while the theory of Childs suggests that the attorney fee deduction should be deferred until payments are made to the attorney, this conclusion is not free from doubt. Childs itself is sloppily reasoned, and the IRS has not yet addressed this situation in guidance or litigation.

Finally, the interaction between the Banks case and the excise tax on transfers of qualified structured settlements must be considered. As discussed earlier, in Banks, the U.S. Supreme Court explained that, in a contingent fee arrangement, the entire recovery (including any portion that is paid to the attorney pursuant to the fee agreement) constitutes gross income to the plaintiff. The plaintiff is then treated as paying her attorney. The conclusion in Banks that the attorney fee portion of the award is deemed to "flow through" the plaintiff on its way to the attorney may result in an unintended application of the excise tax in section 5891.

Enacted by Congress in 2002, section 5891 imposes an excise tax on a "transfer of structured settlement payment rights (including portions of structured settlement payments) made for consideration by means of sale, assignment, pledge, or other form of encumbrance or alienation for consideration." 144 Congress was apparently concerned that plaintiffs were selling their rights to future payments to factoring companies at excessive discounts. The excise tax, which is imposed only on transfers of qualified structured settlements, ${ }^{145}$ is equal to $40 \%$ of the factoring discount, unless the transfer is approved in advance by a

144. I.R.C. $\$ 5891(c)(3)(A)$ (defining "structured settlement factoring transaction"). Section 5891(a) imposes the excise tax "on any person who acquires directly or indirectly structured settlement payment rights in a structured settlement factoring transaction."

145. I.R.C. $§ 5891$ (c)(1)(A) (defining, for purposes of the excise tax, "structured settlement" to include only structured settlements that are covered by the section 104(a)(2) exclusion). 
"qualified [court] order." ${ }^{146}$ The factoring discount is equal to the excess of the total undiscounted future payments owed to the transferee over the present value of the future payments. ${ }^{147}$ For example, if a plaintiff sells ten future annual payments of $\$ 100,000$ for a lump sum payment of $\$ 600,000$, the factoring discount would be $\$ 400,000$ and the tax imposed on the buyer $\$ 160,000$, absent a qualifying court order. To constitute a qualifying court order, the order must determine that, among other things, the transfer "is in the best interest of the payee, taking into account the welfare and support of the payee's dependents." 148

Under Banks, a structured attorney's fee arrangement is deemed to flow through the plaintiff on its way to the attorney. The attorney's rights to receive future payments are treated as first received by the plaintiff and then immediately re-transferred from the plaintiff to the attorney in satisfaction of (in part or in whole) the plaintiff's contingent fee obligation to pay the attorney for legal services. Unless a court order that complies with the specific requirements of section 5891 approves the re-transfer of the payment rights from the plaintiff to the attorney, a significant excise tax could be imposed on the attorney at the time the structured fee arrangement is created, provided that the attorney fee structure would have been characterized as a qualified structure had it been retained by the plaintiff. ${ }^{149}$ This result was surely not intended by Congress, which was focused on protecting plaintiffs from selling their payment rights to factoring companies at huge discounts. Nevertheless, the statute, which is broadly worded, and the Supreme Court's analysis in Banks suggest that the excise tax would apply. Accordingly, attorneys who structure their fees in a physical injury case should consider obtaining a court order that complies with the requirements of section 5891 .

146. I.R.C. § 5891(a), (b).

147. I.R.C. $\S 5891(\mathrm{c})(4)$.

148. I.R.C. § 5891(b)(2)(A)(ii); see also I.R.C. § 5891(b)(2)-(4) (imposing other technical requirements that must be satisfied to qualify for a court order).

149. To be a qualified structure, the damages that were contributed to the structure must be excludable under section 104(a)(2). See supra note 145 . Thus, the excise tax only potentially applies to situations where physically injured plaintiffs are involved (and then only to the extent that the damages contributed into the structure do not represent taxable components, such as punitive damages or interest). In other words, the excise tax has no application to nonqualified structures. 


\section{B. Tax Treatment of Litigation Costs}

Most commonly, litigation costs ${ }^{150}$ paid by contingent fee lawyers are structured as advances from the lawyer to the client. The client will ultimately be responsible for the costs, but the lawyer agrees to front the costs until the case is resolved. When the case is resolved, the client repays the "loan" out of the proceeds of the litigation, with the remaining proceeds divided between the lawyer and the client as provided by the contingent fee contract. If the proceeds of the litigation are insufficient to repay the advances, or if there are no proceeds at all, the client may be personally responsible for the shortfall. Alternatively, the lawyer might agree to not seek repayment of any shortfall, in which case the arrangement is effectively a nonrecourse loan with the cause of action serving as collateral. ${ }^{151}$

The tax issue regarding costs is whether they can be immediately deducted by the lawyers who front them or whether instead they must be capitalized. If the costs are capitalized, the lawyer does not take a deduction in the year in which the costs are incurred but instead the costs are treated as an interest-free loan from the lawyer to the client. When money is loaned, lenders get no deduction. Likewise, when loaned money is repaid, the lender realizes no income. If loaned money is not

150. The Model Contingency Fee Agreement provided by the California bar includes the following list of advanced expenses:

court fees, jury fees, service of process charges, court and deposition reporters' fees, interpreter/translator fees, outside photocopying and reproduction costs, notary fees, long distance telephone charges, messenger and other delivery fees, postage, deposition costs, travel costs including parking, mileage, transportation, meals and hotel costs, investigation expenses, consultant, expert witness, professional mediator, arbitrator and/or special master fees and other similar items.

Form No. 3, Sample Written Fee Agreement, Contingency Fee Agreement, CA. StATE BAR $\uparrow$ 6, http://www.calbar.ca.gov/Portals/0/documents/mfa/2015/2015 _SampleFeeAgreements2-070115_r.pdf (last visited Dec. 3, 2018).

151. A nonrecourse loan is a secured loan where the lender's recourse in the event of default is to foreclose on the collateral. On the other hand, a recourse loan allows the lender to sue the borrower personally for any deficiency. 
repaid (because, e.g., it is forgiven by the lender), the lender generally realizes a deduction. ${ }^{152}$

On the other hand, if costs are immediately deducted, then any repayment of the costs is included in gross income. ${ }^{153}$ If the costs are not repaid, then there is no further deduction. ${ }^{154}$ The differences between the two approaches are summarized in Figure 3. Trial lawyers generally prefer to immediately deduct costs. Immediate deductions reduce the lawyer's tax liability in the current year, though they will increase the lawyer's tax liability in future years. ${ }^{155}$ Nevertheless, this trade-off of less current tax for more future tax is generally a happy one for taxpayers, due to the time-value of money. The immediate deduction approach is also administratively simpler and more intuitive because it allows trial lawyers to treat costs in the same manner that they treat other routine outlays such as office rent, supplies, insurance, advertising, and staff salaries, which are all immediately deductible.

However, the IRS has consistently taken the position that all litigation costs paid by contingent fee lawyers are capitalized, regardless of the technical particularities of the contingent fee agreement. ${ }^{156}$ The IRS has thus far prevailed in all of the reported cases on the issue, ${ }^{157}$

152. See I.R.C. § 166.

153. See I.R.C. $\S 111$.

154. A second deduction would allow the lawyer a double deduction for the costs - first at the time they are paid and then again when they are forgiven.

155. Immediate deduction versus capitalization is simply a "now or later" issue. If costs are deducted, the lawyer realizes a current deduction, but when the client repays the costs, the lawyers will have income (and if the client fails to repay the costs, the lawyer would get no deduction at that time). If costs are capitalized, the lawyer gets no immediate deduction, but when the client repays the costs, the lawyer has no income (and if the client fails to repay the costs, the lawyer would realize a deduction at that time).

156. See, e.g., T.A.M. 1994-32-002 (Mar. 30, 1994); F.S.A. 1997 WL 33313738 (June 2, 1997).

157. See Humphrey, Farrington \& McCain, P.C. v. Comm'r, T.C. Memo 2013-23, 105 T.C.M. (CCH) 1150 (2013); Badell v. Comm'r, T.C. Memo 2000-303, 80 T.C.M. (CCH) 422 (2000); Boccardo v. United States, 12 Cl. Ct. 184 (1987); Silverton v. Comm'r, T.C. Memo 1977-198, 36 T.C.M. (CCH) 817 (1977), aff'd without opinion, 647 F.2d 172 (9th Cir. 1981); Herrick v. Comm'r, 63 T.C. 562 (1975); Canelo v. Comm'r, 53 T.C. 217 (1969), aff'd per curiam, 447 F.2d 484 (9th Cir. 1971); Burnett v. Comm'r, 42 T.C. 9 (1964), aff'd in 
Figure 3:

\begin{tabular}{|l|l|l|l|}
\hline Treatnent of costs & $\begin{array}{l}\text { Payment of costs by } \\
\text { lawyer }\end{array}$ & $\begin{array}{l}\text { Repayment of costs by } \\
\text { client at seftlement }\end{array}$ & $\begin{array}{l}\text { Costs waived (not } \\
\text { repaid by client) }\end{array}$ \\
\hline Immediate deduction & Deduction & Income & No tax consequence \\
\hline Capitalization & No deduction & No income & Deduction \\
\hline
\end{tabular}

with one notable exception involving so-called "gross fee" contingent fee contracts. ${ }^{158}$

Despite the IRS's well-known position on litigation costs and its nearly universal success in the courts, a prominent commentator on litigation-related tax issues believes that " $[t]$ he vast majority of plaintiffs' law firms (either unwittingly or aggressively) probably do deduct client costs as they pay them, rather than waiting until the case settles." 159 In addition, there have been several recent legislative proposals that specifically addressed the tax treatment of litigation costs. Some would have allowed trial lawyers to immediately deduct their costs, ${ }^{160}$ while others would have codified the IRS's position and required capitalization in all situations (including in the context of gross-fee contracts). ${ }^{161}$ None of these proposals have yet been enacted.

While the IRS has generally prevailed in court in arguing for capitalization, it did lose one case in the Ninth Circuit. In that 1995 case, the Boccardo Law Firm had used a gross fee contract in some of its cases. ${ }^{162}$ In the gross fee contracts, the Boccardo Law Firm would simply receive

part, remanded in part on other grounds, 356 F.2d 755 (5th Cir. 1966); Hearn v. Comm'r, 36 T.C. 672 (1961), aff'd, 309 F.2d 431 (9th Cir. 1962).

158. Boccardo v. Comm'r, 56 F.3d 1016 (9th Cir. 1995).

159. Robert W. Wood, A Taxing Process, L.A. DaILY J. 5 (Jan. 13, 2009), http://www.woodllp.com/Publications/Articles/pdf/LDJ0113005.pdf.

160. See, e.g., H.R. 2519, 111th Cong. (2009). The same proposal giving trial lawyers a tax deduction for litigation costs was attached to H.R. 6049 , the Renewable Energy and Job Creation Act, also known as the "tax extenders" legislation in 2008.

161. Both the House and the Senate bills of the 2017 Tax Act would have required capitalization in all instances, but the provision was removed by the conference committee. See Robert W. Wood, Contingent Fee Lawyers Dodge Bullet in Tax Reform, Forbes (Jan. 9, 2018, 8:48 AM), https://www .forbes.com/sites/robertwood/2018/01/09/contingent-fee-lawyers-dodge -bullet-in-tax-reform/\#14e73eb54c7c.

162. See Boccardo v. Comm'r, T.C. Memo 1993-224, 65 T.C.M. (CCH) 2739, 2740 (1993), rev'd, 56 F.3d at 1016 (describing the Boccardo Law Firm's gross fee contract). 
$33.3 \%$ of any pre-trial settlement or $40 \%$ of any post-trial recovery regardless of the amount of litigation costs that it incurred. The IRS took the position that, despite the absence of an obligation to repay the costs incurred by the law firm, the costs still had to be capitalized. At trial, the Tax Court agreed with the IRS, concluding that the gross fee contracts were substantively very similar to nonrecourse advances because of the strong likelihood that the law firm would eventually recoup its costs out of the eventual recovery. ${ }^{163}$

The Ninth Circuit then reversed the Tax Court's decision, determining that the absence of a repayment right in favor of the law firm precluded characterization of the gross fee contract as a loan. ${ }^{164}$ As a result, the Ninth Circuit held that the law firm's immediate deduction of costs was proper. In 1997, the IRS issued a Field Service Advisory that announced that the IRS disagreed with the Ninth Circuit's reasoning and would continue to assert that litigation costs incurred under a gross fee contract had to be capitalized, except in the Ninth Circuit where it was bound by the Boccardo decision. ${ }^{165}$

However, in 2004, nine years after the Boccardo decision, the Treasury Department issued a set of regulations that broadly address capitalization issues relating to intangible assets. ${ }^{166}$ A careful reading of those regulations appears to confirm the correctness of the Ninth Circuit's approach with regard to gross fee contracts. ${ }^{167}$ Thus, in gross fee contracts nationwide lawyers should be able to immediately deduct litigation costs. On the other hand, the 2004 regulations confirm the traditional IRS view that costs in non-gross-fee situations must continue to be capitalized. ${ }^{168}$

163. Boccardo, 65 T.C.M. (CCH) at 2742-43.

164. Boccardo, 56 F.3d at 1018-19 ("It is difficult to see how the label of 'advances' with its implication of 'loans' can be applied as a matter of law to payments when there is no obligation on the part of the client to repay the money expended.").

165. F.S.A. 1997 WL 33313738 (June 2, 1997). The 1997 FSA reiterated the IRS's position in a 1994 Technical Advice Memorandum, which required capitalization of advanced litigation expenses. T.A.M. 1994-32-002 (Mar. 30, 1994).

166. See T.D. 9107, 2004-1 C.B. 447. The regulations are found in Reg. $\S 1.263(\mathrm{a})-4$.

167. See Gregg D. Polsky \& R. Kader Crawford, Must Contingent Fee Lawyers Capitalize Litigation Costs?, 141 TAx Notes 295 (Oct. 21, 2013).

168. See id. at 300. 


\section{The 2017 Tax ACT}

On December 22, 2017, President Donald J. Trump signed Public Law No. 115-97, formerly known as the Tax Cut and Jobs Act of 2017, ${ }^{169}$ into law (the "2017 Tax Act"). The 2017 Tax Act dramatically changed the tax landscape. This Part addresses the changes that are most relevant to trial lawyers with regard to their own personal tax situations. ${ }^{170}$

\section{A. The 20\% Pass-Through Deduction}

\section{In General}

In a very significant change, the 2017 Tax Act added Code section 199A, which allows a $20 \%$ "pass-through deduction" (PTD) for certain business income, subject to limitations and restrictions. If the full $20 \%$ PTD is allowed, it shelters $20 \%$ of the taxpayer's business income, meaning that the taxpayer is only taxed on $80 \%$ of her business income. Another way to view the PTD is that (assuming that it is allowed in full) it reduces the taxpayer's marginal tax rate on business income by $20 \%$. A top-rate taxpayer would therefore see her top federal income tax rate on business income reduced from $37 \%$ to $29.6 \% .{ }^{171}$ Table 1 illustrates the effect of the PTD on marginal rates applicable to business income, assuming that the taxpayer is allowed the full deduction.

The PTD is not an itemized deduction, which means that taxpayers can claim the PTD even if they take the standard deduction. ${ }^{172}$ However, the PTD is not an "above-the-line" deduction, so it does not

169. The official title of the law is "To provide for reconciliation pursuant to titles II and V of the concurrent resolution on the budget for fiscal year 2018."

170. The 2017 Tax Act included some changes that have the potential to significantly impact litigants themselves. The denial of miscellaneous itemized deductions can affect certain plaintiffs. See supra Part I.D. The so-called Harvey Weinstein rule can affect both plaintiffs and defendants in sex abuse or harassment cases. See supra Part I.E (discussing possible effect on plaintiffs) and notes $84-85$ (discussing effect on defendants). In addition, the 2017 Tax Act made important changes to the historic rule that government fines and penalties are per se nondeductible. See I.R.C. $\$ 162(\mathrm{f})$ and supra notes 86-88.

171. $37 \%$ less $(20 \%$ of $37 \%)=29.6 \%$.

172. See I.R.C. $\$ 63($ b)(3) (allowing taxpayer to claim section 199A deduction and the standard deduction). The standard deduction was raised 
Table 1:

\begin{tabular}{lc}
\hline “Ordinary" Marginal Rate & $\begin{array}{c}\text { Effective Marginal Rate } \\
\text { on Business Income }\end{array}$ \\
\hline $10 \%$ & $8 \%$ \\
$12 \%$ & $9.6 \%$ \\
$22 \%$ & $17.6 \%$ \\
$24 \%$ & $19.2 \%$ \\
$32 \%$ & $25.6 \%$ \\
$35 \%$ & $28 \%$ \\
$37 \%$ & $29.6 \%$ \\
\hline
\end{tabular}

reduce the taxpayer's adjusted gross income. ${ }^{173}$ Adjusted gross income is a measure that affects the ability to claim other deductions, such as the medical expense deduction. ${ }^{174}$

The PTD applies only to income earned by individuals either directly ${ }^{175}$ or through a pass-through entity, such as an S corporation, ${ }^{176}$ partnership, limited liability company, limited liability partnership, or other non-corporate entity. ${ }^{177}$ Non-corporate entities are generally considered "partnerships" for federal tax purposes and their owners

significantly in the 2017 Tax Act, and some itemized deductions were severely limited or eliminated. See supra note 11 and accompanying text.

173. See I.R.C. \$ 62(a) (listing above-the-line deductions and omitting section 199A deduction).

174. See supra note 10 and accompanying text. Adjusted gross income is also often used as the starting point for state income taxes.

175. Direct income includes sole proprietorship income. It also generally includes income of non-corporate entities (such as LLCs) that have only one member. These single member non-corporate entities are disregarded for federal income tax purposes, which means that their income is treated as sole proprietorship income by the IRS. See Reg. § 301.7701-3(b)(1)(ii).

176. An $\mathrm{S}$ corporation is a special corporation that does not itself pay tax; instead, its income and deductions pass-through to the owners. I.R.C. $\S 1361$ et seq. The same pass-through taxation applies to partnerships and other non-corporate entities. To be an S corporation, the corporation generally must have only U.S. individuals as shareholders and only one class of stock, among other requirements; in addition, a valid $\mathrm{S}$ corporation election must be in effect. See I.R.C. $\S \S 1361-1363$.

177. See I.R.C. $\S 199$ A(a) (allowing deduction "[i]n the case of a taxpayer other than a corporation"). 
"partners," and such terminology will be used in this Article. ${ }^{178} \mathrm{C}$ corporations ${ }^{179}$ are not allowed to claim the PTD. (Under the 2017 Tax Act, C corporations instead received the benefit of drastically reduced corporate tax rates, as discussed below in Part VI.B.)

Business income that is eligible for the PTD is generally income earned by an individual (directly or indirectly) subject to two important carve-outs. First, wages earned by an employee do not generate the PTD. ${ }^{180}$ Therefore, employees of any businesses will not benefit from the PTD. Second, "guaranteed payments" received by partners of partnerships do not generate the PTD. ${ }^{181}$ Guaranteed payments are defined as payments that are made to partners that are "determined without regard to the income of the partnership." 182 On the other hand, payments to partners that can vary depending on the success of the business are not guaranteed payments. ${ }^{183}$

For taxpayers with income below certain thresholds, these two carve-outs (for wages and guaranteed payments) are the only impediments to claiming the PTD. Specifically, for married taxpayers with taxable income below $\$ 315,000$ and unmarried taxpayers below $\$ 157,500$,

178. See generally Reg. $\$ 301.7701-3$. These non-corporate entities can elect to be treated as corporations for income tax purposes. See Reg. $\$ 301.7701-3$ (a). This Article assumes that no such election has been made.

179. C corporations are corporations that are not $\mathrm{S}$ corporations, either because they are not eligible to be $\mathrm{S}$ corporations or because they have not made a valid $S$ corporation election.

180. I.R.C. $§ 199 \mathrm{~A}(\mathrm{~d})(1)(\mathrm{B})$. In addition, if a business is operated as an $\mathrm{S}$ corporation, the IRS can recharacterize distributions to an owner-employee as wages if the stated wages of the owner-employee are unreasonably low. See, e.g., David E. Watson, P.C. v. United States, 714 F. Supp. 2d 954 (S.D. Iowa 2010). In such a case, the recharacterized wages would not be eligible for the section 199A deduction.

181. See I.R.C. § 199A(c)(4)(B).

182. I.R.C. \$ 707(c).

183. However, section 199A(c)(4)(C) allows the IRS to exempt certain "disguised compensation" distributions. This would apply where payments to a partner appear to be subject to the business risks of the partnership but in substance are not. For example, a payment of the first $\$ 100,000$ of gross income to a partner in a partnership that routinely generates $\$ 10,000,000$ of gross income would be treated as disguised compensation, which means that the payee partner would not get the benefit of the section 199A deduction with respect to the $\$ 100,000$ payment. 
the PTD is allowed in full for business income other than wages and guaranteed payments. ${ }^{184}$ Above those limits, the PTD gradually phases out until it is potentially eliminated at taxable income levels of $\$ 415,000$ and $\$ 207,500$, respectively, for married and unmarried taxpayers.

For taxpayers above the $\$ 315,000 / \$ 157,500$ taxable income limits, other hoops must be jumped through in order to claim the full PTD. First, there is a blanket exception for "specified service" income. ${ }^{185}$ Specified services include the performance of services in the fields of law, health, accounting, actuarial science, performing arts, consulting, athletics, financial services, brokerage services, or the performance of any business where the principal asset of such trade or business is the reputation or skill of one or more of its employees or owners. ${ }^{186}$ Second, for other income, there is the following limitation. The PTD amount, which is tentatively $20 \%$ of business income, is capped at the greater of: (1) $50 \%$ of the amount of W-2 wages paid by the business and (2) $25 \%$ of the amount of $\mathrm{W}-2$ wages paid by the business, plus $2.5 \%$ of the original cost of the business's tangible depreciable property. ${ }^{187}$

\section{Potential Pass-Through Deduction Strategies for Lawyers}

Because of the inclusion of the practice of law as a specified service, the PTD opportunities for lawyers are somewhat constrained. Potential PTD strategies for lawyers can be grouped into one of two categories. First, there are strategies for law practices where some lawyers will earn less than the $\$ 415,000$ (married) $\$ 207,500$ (unmarried) taxable income thresholds. These strategies attempt to reclassify W-2 wages and guaranteed payments so as to allow payees to claim the PTD. Second, there are potential strategies to restructure, recharacterize, or otherwise recast legal services income as other types of business income to avoid the

184. I.R.C. $\$ 199 \mathrm{~A}$ (b)(3) (exempting taxpayers below income thresholds from the W-2 wages limits), (d)(3) (exempting taxpayers below income thresholds from the specified services exclusion), (e)(2) (defining threshold amounts). For this purpose, taxable income is computed without regard to the PTD. I.R.C. $\$ 199 \mathrm{~A}(\mathrm{e})(1)$. Thus, it is the excess of gross income over all allowable deductions (including the standard deduction) other than the PTD.

185. I.R.C. § 199A(d)(1)(A).

186. See I.R.C. $§ 199 A(d)(2)(A)$.

187. I.R.C. $\$ 199 \mathrm{~A}(\mathrm{~b})(2)(\mathrm{B})$. The rules for calculating $2.5 \%$ of the original cost of tangible depreciable property are found in section 199A(b)(6). 
"specified services" taint, although recently proposed Treasury regulations would, if finalized, significantly impair their viability. ${ }^{188}$

\section{a. Strategies for Lawyers Below the Income Thresholds}

For taxpayers above the $\$ 415,000 / \$ 207,500$ taxable income thresholds, legal services income is completely ineligible for the PTD. For taxpayers below the $\$ 315,000 / \$ 157,5000$ thresholds, legal services income is entirely eligible for the PTD unless the income is in the form of wages earned by an employee or guaranteed payments earned by a partner. For taxpayers between those two thresholds (i.e., between $\$ 315,000$ and $\$ 415,000$ for married persons or between $\$ 157,500$ and $\$ 207,500$ for unmarried persons), the PTD is partially allowed for legal services income, provided that it is not in the form of wages or guaranteed payments.

For lawyers who will earn taxable income below these thresholds, they will be better off as partners rather than employees. This is because partners can receive the PTD (except with respect to the receipt of guaranteed payments), while employees cannot. In addition, partners who receive non-guaranteed payments are better off compared to those who receive salaries or guaranteed payments.

To illustrate, assume that a married associate at a law firm is expected to earn $\$ 200,000$ in wages and that the associate's joint married income will be less than $\$ 315,000$. Absent any restructuring, the $\$ 200,000$ of wages is ineligible for the PTD. But if the associate is elevated to junior partner and earns the same amount, the PTD is allowed unless the payments are treated as guaranteed payments. To avoid guaranteed payment status, the lawyer's rights to payments from the firm must be dependent on the success of the law firm. For example, if the lawyer's rights to payments are ultimately determined by the managing partner based on the overall success of the law firm and the lawyer's personal contributions to that success, all of the payments would not be guaranteed and therefore they will be eligible for the PTD. But if the lawyer is contractually guaranteed a minimum payment of $\$ 100,000$ and ultimately receives $\$ 225,000$, then only $\$ 125,000$ is eligible for the PTD.

Before embarking on this strategy, several factors must be carefully considered. First, making the associate a partner will have other

188. See 83 Fed. Reg. 40884 (Aug. 16, 2018). 
tax effects. Partners are not employees, so instead of the associate receiving wages that are subject to withholding, she will now receive selfemployment income to which withholding does not apply. This means that she will be required to make quarterly estimated tax payments. She will also no longer receive weekly, bi-weekly, or monthly paychecks but instead will receive periodic "draws" of partnership income. She will be liable to repay these draws to the extent they exceed her ultimate distributive share of the law firm's income, which will be determined by the managing partner. Also, as a self-employed person, she will pay both sides of employment taxes, whereas when she was an employee she paid only the employee's half, with the law firm paying the other half. This can be fairly easily taken into account in setting the amount of payments. If an employee earns $\$ 200,000$ in 2018 , the employer will pay about $\$ 11,000$ in employer-side employment taxes. So the law firm could pay the junior partner $\$ 211,000$.

Second, the strategy imposes additional risk on the new junior partner. Whereas before she received a fixed salary and perhaps a contingent bonus, now (to maximize the PTD) all of her pay is contingent, at least as a technical legal matter. There is no such risk with respect to salaries or guaranteed payments.

Third, the IRS might reject the claimed partner status of the new junior partner. Recently issued proposed regulations include a presumption that a new junior partner remains an employee. ${ }^{189}$ This presumption may be rebutted by the new junior partner upon a showing that she is in fact performing services in a partner capacity (as opposed to an employee capacity). Thus, for example, if the new junior partner can establish that her income allocation is significantly contingent on the law firm's profitability and that she now participates in management decisions, she will be able to rebut this presumption. ${ }^{190}$ However, if her relationship with the other partners of the law firm is materially unchanged, then the IRS would continue to treat her as an employee.

Finally, there are other legal distinctions between employee status and partner status. For example, partners owe and may be owed

189. See Prop. Reg. $\$ 1.199$ A-5(d)(3)(i), 83 Fed. Reg. 40884, 40927 (Aug. 16, 2018).

190. Cf. Prop. Reg. § 1.199A-5(d)(3)(ii), Ex. 3, 83 Fed. Reg. 40884, 40927 (Aug. 16, 2018) (explaining that engineer's promotion to partner would be respected in part because the engineer now shares in the overall net profits of the engineering firm). 
certain fiduciary duties that do not apply in equal force with regard to employees. And, from an employee benefits perspective, partners are often distinguished from employees.

Therefore, while in theory the transformation from mostly fixedpay employee to contingent-pay partner is an easy strategy to generate PTD-eligible income, in practice the transformation might not be worth the hassle. Each situation must be assessed based on its own facts and circumstances.

\section{b. “Cracking” Legal Services Businesses}

Above the income thresholds, creating PTD for lawyers is much trickier due to the specific carve-out of legal services as a specified services business. One possibility is to re-characterize legal services income as other types of income. Commentators have discussed the possibility of "cracking" a PTD-ineligible line of business into separate components, some of which could be PTD eligible.

For example, a law firm that owns its real property might create a separate entity to own the property and lease it to the law firm. To be successful, the leasing activity would have to constitute a trade or business, which requires a requisite amount of continuous and regular activity. ${ }^{191}$ In addition, sufficient wages must be paid by the leasing business (or property owned by the leasing business) to allow for significant PTDs to satisfy the "greater of" test. ${ }^{192}$ And the lease rate must be consistent with market rates. ${ }^{193}$

A similar strategy could be attempted with regard to other ancillary activities of a legal practice. The Wall Street Journal recently reported on an immigration law firm's strategy to split its operations between its legal practice (which would employ the firm's lawyers) and its administrative work, which would be handled by the firm's 26-person administrative staff. ${ }^{194}$ The latter entity would "put together

191. See generally Comm'r v. Groetzinger, 480 U.S. 23 (1987).

192. See supra notes $186-187$ and accompanying text (describing the PTD limit to the greater of $50 \%$ of wages paid or the sum of $25 \%$ of wages paid plus $2.5 \%$ of property cost).

193. See generally I.R.C. $\$ 482$ (allowing the IRS to reallocate income and deductions among related taxpayers so as to properly reflect income).

194. See Ruth Simon \& Richard Rubin, Crack and Pack: How Companies Are Mastering the New Tax Code, WALL ST. J. (Apr. 3, 2018), https:// 
immigration applications and handle other tasks." ${ }^{195}$ If this restructuring were respected by the IRS, the latter entity's profits would be eligible for the PTD (subject to the "greater of" test) because that entity's business does not engage in the practice of law or in any other specified services. ${ }^{196}$ However, it is quite possible that the IRS would treat the businesses as a single integrated law practice, which would eliminate the ability to claim the PTD.

Likewise, a law firm could attempt to split off its intellectual property rights into a separate entity and have the law firm lease those rights. Or a law firm that engages in non-legal work such as trusteeships, personal representative activities, title-agent work, or expert-witness activities could attempt to segregate these activities in an attempt to generate the PTD.

However, recently proposed Treasury regulations would, if finalized, make these strategies ineffective. These proposed regulations explain that, if there is more than $50 \%$ common ownership between the law firm and the ancillary real estate or other business and if the ancillary business provides $80 \%$ or more of its property or services to the law firm, then the income of ancillary business will be deemed to be legal services income that is ineligible for the PTD. ${ }^{197}$ In addition, if there is more than $50 \%$ common ownership but less than $80 \%$ of the property or services is provided to the law firm, then the rent or fees paid by the

www.wsj.com/articles/crack-and-pack-how-companies-are-mastering-the -new-tax-code-1522768287?ns=prod/accounts-wsj.

195. Id.

196. The prices paid by the law firm entity to the administrative services entity would have to be consistent with an arm's length arrangement. See supra note 193 and accompanying text. The taxpayer would like to have the law firm pay as generous a rate as possible because any excess profits realized by the administrative services entity (at the expense of the law firm entity) would, if respected, be eligible for the PTD. Thus, for every $\$ 100$ of profit so shifted, a taxpayer in the highest marginal tax rate could save $\$ 7.40$ in federal taxes.

197. See Prop. Reg. § 1.199A-5(c)(2)(i), 83 Fed. Reg. 40884, 40926 (Aug. 16, 2018). An example considers the situation where a law firm rents its building and buys administrative services from two separate partnerships, both of which are owned entirely by law firm partners. In addition, all of the rental and services income of the two partnerships stem from the law firm. The example concludes that the rental income and administrative services income is treated as legal services income. See Prop. Reg. § 1.199A-5(c)(2)(iv), 83 Fed. Reg. 40884, 40926 (Aug. 16, 2018). 
law firm to the ancillary business will be deemed to be legal services income ${ }^{198}$ If these parts of the proposed regulations are finalized, they will be retroactively effective back to the enactment date of the 2017 Tax Act. ${ }^{199}$

\section{B. Drastically Reduced Corporate Rates}

Prior to the 2017 Tax Act, the income of $\mathrm{C}$ corporations was taxed at a maximum rate of $35 \%$. The $35 \%$ top rate for corporations had been in effect for many years. The 2017 Tax Act reduced that rate to $21 \%$. On the other hand, the top individual rate dropped only from $39.6 \%$ to $37 \%$. In addition, while the state and local tax deduction for individuals was limited by the 2017 Tax Act to a maximum of $\$ 10,000$, the state and local tax deduction for corporations remains unlimited.

Because of these changes, businesses that cannot easily get the PTD, such as those in specified services, may consider converting their entity to a C corporation. ${ }^{200}$ This is particularly true if the owners of the business intend to leave a significant amount of the profits in the business, where they can compound while paying taxes at the much lower corporate rate.

However, such a strategy is risky and must be carefully evaluated. While corporate tax rates are now low, it is a distinct possibility that they will go up in the future. While less likely, it is also possible that individual tax rates could go down. Compounding these risks, while it is very easy (tax-wise) to convert a partnership to a corporation, the inverse is often highly problematic.

\section{Enlarged Expensing}

The 2017 Tax Act extended "bonus depreciation" rules that allow taxpayers to immediately deduct the cost of certain tangible business

198. See Prop. Reg. § 1.199A-5(c)(2)(ii), 83 Fed. Reg. 40884, 40926 (Aug. 16, 2018).

199. See Prop. Reg. § 1.199A-5(e)(2)(i), 83 Fed. Reg. 40884, 40927 (Aug. 16, 2018).

200. If a specified services business is already a $\mathrm{C}$ corporation, it may consider retaining more of its profits. Historically, these businesses would tend to "zero out" their corporate income by paying out all of their income in the form of wages and bonuses. 
property, such as office equipment and furniture, instead of claiming annual depreciation deductions over time. Previously, bonus depreciation applied strictly to new property (as opposed to property that had previously been used by another person) and only $50 \%$ of a property's cost could be immediately deducted. After the 2017 Tax Act, used property is eligible and the entire cost of the property can be immediately deducted. ${ }^{201}$ The new bonus depreciation rules are scheduled to gradually phase out beginning in 2023 and will (absent further legislative action) fully expire on December $31,2026 .{ }^{202}$

The 2017 Tax Act also enlarged section 179, which allows small businesses to immediately deduct the cost of certain tangible business property. New section 179 allows up to $\$ 1$ million (up from $\$ 500,000$ ) of such property to be immediately deducted, and it begins to phase out once a taxpayer places more than $\$ 2.5$ million (up from $\$ 2$ million) of such property into service. Unlike the changes to bonus depreciation, which are scheduled to fully expire in 2026, the changes to section 179 are permanent.

\section{Conclusion}

As this Article has shown, a whole host of tax issues can arise in the personal injury context. The taxation of plaintiffs can be quite complicated, especially after the 2017 Tax Act's elimination of miscellaneous itemized deductions. Tax allocations in settlement agreements are very important, and because of the information reporting requirements placed on defendants and insurance companies (and the corresponding liability for under-reporting), negotiations over allocations can be fraught. Structured settlements, both qualified and nonqualified, can provide significant tax benefits for plaintiffs who intend to invest a substantial amount of their recoveries.

Tax information may also constitute admissible evidence. Defendants may seek to introduce the tax-free nature of certain recoveries to reduce their exposure. While defendants have generally not been successful in this regard, in discrimination cases plaintiffs have successfully used tax evidence to augment their awards to counteract certain adverse tax consequences.

201. I.R.C. $\S 168(\mathrm{k})(2)(\mathrm{A})(\mathrm{ii})$.

202. I.R.C. $\S 168(\mathrm{k})(6)(\mathrm{A})$. 
Finally, plaintiff's lawyers face their own interesting personal tax issues. Attorney fee structures may be used to reduce the present value of their tax burden. The tax treatment of litigation advances remains muddled and counter-intuitive. In addition, the 2017 Tax Act has created a number of potential tax planning options for these lawyers. 